\title{
Erythropoietin and cancer: the unintended consequences of anemia correction
}

\author{
Nataša Debeljak ${ }^{1}$ *, Peter Solár ${ }^{2}$ and Arthur J. Sytkowski ${ }^{3}$ \\ 1 Faculty of Medicine, Institute of Biochemistry, University of Ljubljana, Ljubljana, Slovenia \\ ${ }^{2}$ Department of Cell and Molecular Biology, Institute of Biology and Ecology, Faculty of Sciences, Pavol Jozef Šafárik University, Košice, Slovakia \\ ${ }^{3}$ Oncology Therapeutic Area, Quintiles Transnational, Arlington, MA, USA
}

Edited by:

Pietro Ghezzi, Brighton and Sussex Medical School, UK

\section{Reviewed by:}

Ralf Schindler, Charité, Germany

Domenico Ribatti, University of Bari Medical School, Italy

Chris Thiemermann, Queen Mary

University of London, UK

*Correspondence:

Nataša Debeljak, Faculty of Medicine, Institute of Biochemistry, University of Ljubljana, Vrazov trg 2, SI-1000

Ljubljana, Slovenia

e-mail:natasa.debeljak@mf.uni-lj.si

Until 1990, erythropoietin (EPO) was considered to have a single biological purpose and action, the stimulation of red blood cell growth and differentiation. Slowly, scientific and medical opinion evolved, beginning with the discovery of an effect on endothelial cell growth in vitro and the identification of EPO receptors (EPORs) on neuronal cells. We now know that EPO is a pleiotropic growth factor that exhibits an anti-apoptotic action on numerous cells and tissues, including malignant ones. In this article, we present a short discussion of EPO, receptors involved in EPO signal transduction, and their action on nonhematopoietic cells. This is followed by a more detailed presentation of both pre-clinical and clinical data that demonstrate EPO's action on cancer cells, as well as tumor angiogenesis and lymphangiogenesis. Clinical trials with reported adverse effects of chronic erythropoiesis-stimulating agents (ESAs) treatment as well as clinical studies exploring the prognostic significance of EPO and EPOR expression in cancer patients are reviewed. Finally, we address the use of EPO and other ESAs in cancer patients.

\footnotetext{
Keywords: erythropoietin, erythropoietin receptor, receptor partners, cancer, cell response, angiogenesis, clinical trials
}

\section{INTRODUCTION}

The presence of a circulating hemopoietic factor controlling the red blood cell (RBC) production was first suggested in 1906 (1). This humoral factor was experimentally confirmed almost half a decade later and the name erythropoietin was given (2). In 1977, the protein was isolated from human urine (3) enabling research toward cloning of the gene, its characterization, and in vitro expression $(4,5)$. Only 4 years later, the US Food and Drug Administration (FDA) approved the first commercially available recombinant human erythropoietin (rHuEPO), epoetin alfa, for the treatment of anemia associated with chronic kidney disease (CKD) (6). Later on, it was approved also for use in patients with other anemias including cancer patients undergoing chemotherapy (7). Thereafter, rHuEPO became a leading drug for treatment of anemia virtually abolishing the need for RBC transfusion in some types of anemia. As a result, since the 1990s, several new erythropoiesis-stimulating agents (ESA) have become available on the market or are under development [reviewed in Ref. (8)].

Erythropoietin (EPO) was first considered to have a single biological purpose and action - the stimulation of RBC growth and differentiation and, as such safe, for use in cancer patients. Slowly, scientific and medical opinion evolved, beginning with the discovery of an effect on endothelial cell growth in vitro (9) and the identification of EPO receptors (EPORs) on neuronal cells (10). We now know that EPO is a pleiotropic growth factor that exhibits an anti-apoptotic action on numerous cells and tissues, including malignant ones [reviewed in Ref. (11-13)]. In this article, we present a short discussion of EPO, its signaling, and its action on non-hematopoietic cells. This is followed by a more detailed presentation of both pre-clinical and clinical data that demonstrate EPO's diverse actions on cancer cells as well as possible receptors involved in the response of cancer cells to EPO/ESA therapy. Finally, we review current recommendations for the use of rHuEPO and other ESAs as supportive therapy in cancer patients with anemia that often develops during the radioor chemotherapy.

\section{ERYTHROPOIETIN}

The human $E P O$ gene spans over $3 \mathrm{~kb}$ and contains five exons encoding a 193 amino acid protein $(4,5)$. It is a single copy gene located on chromosome 7 at position $7 \mathrm{q} 22(14,15)$. A single splice variant of $E P O$ gene is known (http://www.ncbi. nlm.nih.gov/gene/2056). Gene expression is regulated by oxygen levels through hypoxia. Transcription factors involved are stimulatory HIF-2, HNF-4alpha and inhibitory GATA-2, NF-kappaB [reviewed in Ref. $(16,17)]$.

During post-translation modification, the N-terminal 27 amino acid signal peptide is cleaved and R166 removed resulting in a 165 amino acid mature protein (18). Urinary protein containing 166 amino acids has also been characterized (19). The single-chain protein is heavily glycosylated with a molecular weight ranging from 30 to $39 \mathrm{kDa}$. Three N-linked (N24, N38, and N83) and one O-linked (S126) oligosaccharide side chains represent $35-40 \%$ of the EPO molecular mass. Protein structure is stabilized with two intra-chain disulfide bridges between C7-C161 and C29-C33 (19, 20). N glycosylation does not affect hormone function in vitro but is essential for in vivo biological activity like biosynthesis, structural stability, secretion, plasma half-life, and clearance (21-23). 
In adult human beings, the hormone is produced mainly by the renal cortex $(24,25)$, while in the developing fetus, the liver is the principal source (26). EPO is secreted into the bloodstream, circulates to the bone marrow, and binds to EPOR situated on the cell surface of erythroid progenitors promoting their survival, proliferation, and differentiation (27). EPO is also produced by numerous non-hematopoietic cells and may act in endocrine, autocrine, and paracrine manner (28).

Commercially available rHuEPO has the same 165 amino acid sequence as naturally occurring hormone (29). However, the level of glycosylation in $\mathrm{rHuEPO}$ depends on the expression system used (30). Glycosylation pattern can be analyzed by isoelectric focusing enabling, thus distinguishing endogenous EPO (eEPO) from rHuEPO (31). Also, urinary and serum EPO have some minor heterogeneity in glycosylation levels (32).

\section{ERYTHROPOIETIN SIGNAL TRANSDUCTION}

In classical signal transduction in erythropoiesis, one EPO molecule binds to an EPOR homo-dimer leading to activation of the
EPO-EPOR signaling cascade. EPO has two non-identical binding sites toward EPOR receptors, a high-affinity G151 (nano-molar) to the first, and a low-affinity R103 (micro-molar) interaction to the second receptor (33). Main signaling pathways activated by EPO are JAK2/STAT5 pathway, phosphatidylinositol 3-kinase (PI3K) pathway, RAS/MAP kinase pathway, and protein kinase $\mathrm{C}$ (PKC) pathway (34) (Figure 1). The JAK2/STAT5 and RAS/MAP kinase (RAS-RAF-MEK-ERK) pathways are associated with hormone mitogenic action, while the PI3K pathway (PI3K-AKT) is related with anti-apoptotic activities (27).

In non-hematopoietic tissue, some other receptor partners have been proposed, including the beta common receptor $(\beta \mathrm{cR})(35)$ and the epinephrine B4 receptor (EPHB4) (36). The EPO molecule was indicated to bind to the hetero-dimmer EPOR-EPHB4 or hetero-trimmer EPOR- $\beta$ CR-EPOR. Most probably, the highaffinity site is involved in binding to EPOR, while other receptor partners are bound with low affinity or an alternative site resulting in activation of different, tissue-protective part of EPO-EPOR signaling cascade.

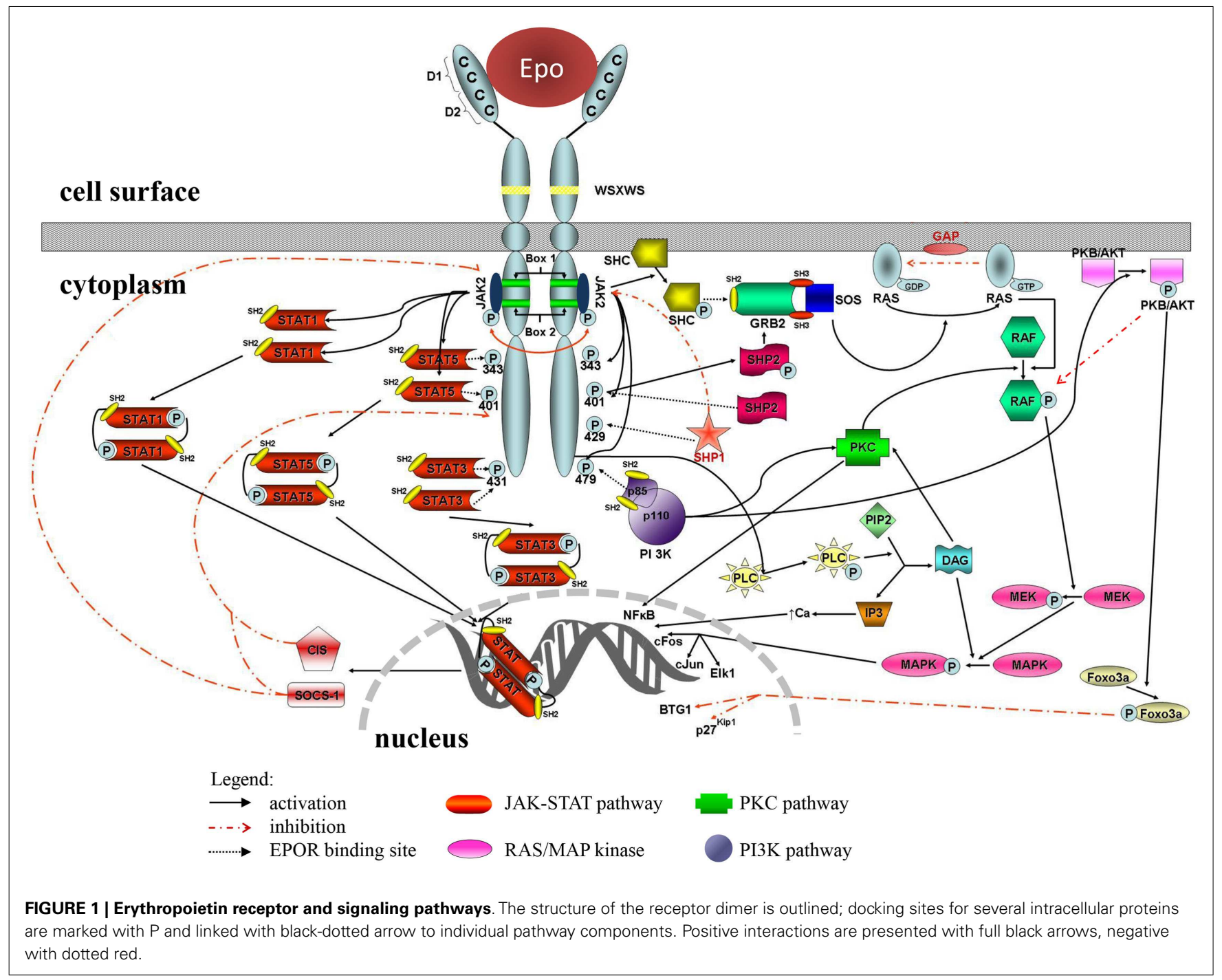




\section{Erythropoietin receptor}

The human EPOR gene spans over $6 \mathrm{~kb}$ and contains 8 exons encoding a 508 amino acid protein (37). The gene is located on chromosome 19 at position 19p13.3-p13.2 (38, 39). Several EPOR splice variants are known such as non-coding RNA, functional transmembrane protein (EPOR-F), truncated protein (EPOR-T), and at least one soluble variant (EPOR-S) (40-42) (http://www.ncbi.nlm.nih.gov/gene/2057).

EPO receptor is a member of the type I cytokine receptor superfamily (43). During post-translation modification, the N-terminal 24-amino acid signal peptide is cleaved and the protein is modified by glycosylation, phosphorylation, and ubiquitination to a mature $66-105 \mathrm{kDa}$ protein $(38,44,45)$. Mature human receptor consists of extracellular, single transmembrane, and cytoplasmic regions (46) (Figure 1).

The majority of the EPOR is located on the cell surface of erythroid progenitors, erythroid burst-forming units (BFU-E), and erythroid colony-forming units (CFU-E) in the bone marrow. However, the EPOR is expressed by various other tissues such as brain, heart, liver, and others where it is involved in the tissue protection. As EPOR is present in various cancer cells, the use of rHuEPO in cancer patients may be problematic due to potential activation of EPO-EPOR signaling pathways resulting in tumor protection (anti-apoptotic action) or proliferation (mitogenic action).

\section{Beta common receptor $(\boldsymbol{\beta c R})$}

The human colony-stimulating factor 2 receptor, beta (CSF2RB) gene contains 14 exons and is located on chromosome 22 at position 22q13.1 (http://www.ncbi.nlm.nih.gov/gene/1439). CSF2RB gene encodes $\beta$-common receptor $(\beta c R)$, a common beta chain subunit of the high-affinity receptor for interleukin 3 (IL3), interleukin 5 (IL5), and CSF2 (granulocyte-macrophage colonystimulating factor).

The interaction of EPOR with the $\beta c R$ was discovered and tissue protection may be signaling through a heteroreceptor complex involving EPOR and $\beta c R$ (35). This signaling network is still not understood but may involve signal pathways different from those triggered by EPOR-EPOR (47-50). The tissue-protective effects of EPO could be mediated by an EPOR heteroreceptor dimer EPOR- $\beta c R$ or trimmer EPOR- $\beta c R-E P O R$ (Figure 2).

\section{Ephrin type-B receptor 4 (EPHB4)}

The human Ephrin receptor B4 (EPHB4) gene contains 17 exons and is located on chromosome 7 at position $7 q 22$ (http://www. ncbi.nlm.nih.gov/gene/2050). Ephrin receptors were named Eph after the EPO-producing hepatocellular carcinoma cell line from which its cDNA was isolated. They form the largest family of receptor tyrosine kinase (RTK) family. About 16 ephrin receptor genes (EphA1-10, EphB1-6) have been identified in the vertebrate genome (51), 14 of which are present in human beings. Ephrin receptors and their ligands, the ephrins, mediate numerus developmental processes. The protein encoded by EPHB4 gene binds to ephrin-B2 ligand and plays an essential role in vascular development. EPHB4 was indicated also as survival factor in several cancers $(52,53)$.
European patent application [EP 2492355 A1 (36)] discloses a molecular composition(s) of a novel tissue-protective EPO-binding receptor protein complex, termed NEPOR. NEPOR represents a novel EPOR derived from a unique combination of EPOR heteroreceptor dimer EPOR-EPHB4, homoreceptor EPOREPOR, and EPHB4-EPHB4, and other components derived from ephrin biology (Figure 3).

\section{Other partners}

Interaction of EPOR with several receptors has been indicated. Some interactions were suggested only on the level of receptor
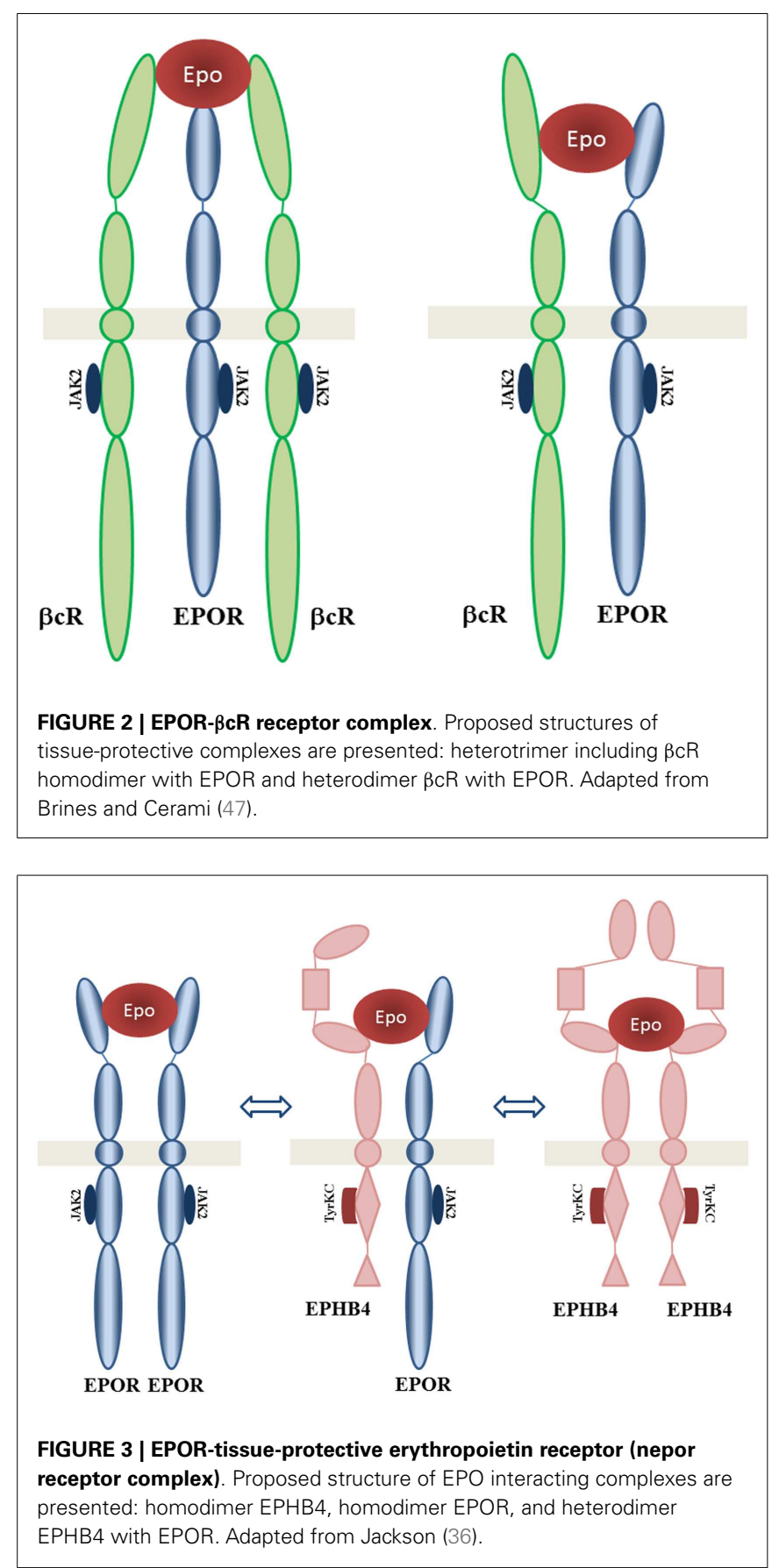
expression correlation $(54,55)$, others on adverse tumor response to receptor-specific therapy $(56,57)$. The exact mechanisms of these correlations is not known yet but are being intensively studied.

Increased EPOR expression was related to a reduced response to tamoxifen treatment, an estrogen receptor (ER) specific inhibitor (56). Furthermore, EPOR receptor was shown to enhance ER activity and promote cell proliferation (58). Several correlations between EPOR, ER, and other steroid receptors expression have been described $(54,55,59,60)$.

The antagonistic effect of EPOR and human epidermal growth factor receptor-2 (HER2) co-expression on transtuzumab therapy, a HER2 inhibiting antibody has also been observed (57). The JAK2-mediated activation of SRC and inactivation of PTEN have been proposed as underlying mechanisms.

\section{ACTION OF EPO ON NON-HEMATOPOIETIC CELLS}

EPO and its receptor have been identified in several nonhematopoietic cells and tissue types like central nervous system, heart, kidney, gastrointestinal system, reproductive tract, endothelium, and others [reviewed in Ref. $(11,12,61)$ ]. In these tissues, EPO was shown to be tissue protective in an anti-apoptotic and/or mitogenic manner. Several ongoing pre-clinical and clinical trials are exploring the potential use of rHuEPO and other ESAs, such as tissue-protective agents in the brain, heart, and wound healing [reviewed in Ref. $(62,63)]$.

Furthermore, EPORs have been found also on several types of tumors and malignant cells [reviewed in Ref. (64-67)] questioning the use of recombinant EPO in cancer patients (68). We will now focus on a review of various effects of EPO and its receptor on cancer cells, being an update of EPO research reviewed by Szenajch et al. (13).

\section{EPO AND CANCER CELLS RESPONSE}

The presence of functional EPOR was demonstrated in cancer stem cells (69-71). Different types of tumors as well as cell lines have been found to express EPOR mRNA transcripts, which might be translated into full-length EPOR as well as soluble or other truncated forms (40). In this regard, Um et al. (72) measured internalized ${ }^{125} \mathrm{I}$-EPO and found that just 50 high-affinity cell surface EPO binding sites were sufficient for EPO-mediated activation of intracellular signal transduction in SH-SY5Y and PC-12 cancer cells. EPOR expression has been demonstrated by flow cytometry using a specific EPOR antibody in a panel of 29 tumor cell lines, including 18 adherent cell lines (73).

Despite the fact that many tumor cells were confirmed to possess the EPOR, there is still some debate on stimulatory effects of EPO on these cells. On the one hand, there are papers pointing to the proliferative response of cancer cells after rHuEPO treatment $(55,74-82)$; on the other hand, some tumor cells, in spite of evidence of EPOR functionality $(67,81)$, did not exhibit a growth response $(67,83-86)$. Our previous studies revealed a weak surface EPOR signal in A2780 cells with most of EPOR found in the cytoplasm, more abundantly as an intracellular membrane-associated protein than a soluble one. Silencing EPOR expression resulted in reduced A2780 proliferation as well as a reduction in EPOinduced phosphorylation of ERK1/2 (81). Unlike hematopoietic cells, where EPO-EPOR signaling is associated with increased cell proliferation and/or survival, in tumor cells, the EPO-EPOR axis does not always lead to increased proliferation but might increase the resistance of cancer cells to different therapies. For more information about the role of EPO and its receptor in growth, survival, and therapeutic response of human cancer cells, see the critical review of Szenajch et al. (13), where all information based on published EPO papers through 2010 is well summarized.

Recently, the presence of EPOR signaling and EPO-induced cellular proliferation was confirmed in renal cancer cells $(80,82)$, head and neck squamous cell carcinomas (77), and cervical cancer cell lines (78), as well as glioma cells (87).

Erythropoietin-induced proliferation of cancer cells was associated with the activation of JAK2, JAK3, STAT3, and STAT5 but not JAK1 or STAT1 (78), AKT phosphorylation (77), ERK phosphorylation (87) with hTERT gene transcription by JAK2/STAT5/cMYC, and hTERT protein phosphorylation by PI3K/AKT (88). Furthermore, the EPO-EPOR pathway stimulated the expression of cyclin D1 and inhibiting the expression of p21cip1 and p27kip1 through the phosphorylation of JAK2 and ERK1/2, led to a more rapid progression through renal cancer cell cycle (82). Interestingly, EPO or stem cell factor (SCF) alone produced a modest number of cervical cancer cell colonies, whereas the combination EPO/SCF induced a significantly more. Similarly, co-stimulation with EPO/SCF induced a significantly higher number of migrating cervical cancer cells than either cytokine alone. Concurrently, EPO induced a modest, transient activation of ERK1/2, whereas SCF and EPO/SCF prompted a strong, sustained phosphorylation of ERK1/2 (89).

Erythropoietin was also involved in cell growth, invasion, survival, and sensitivity to the multikinase inhibitor sunitinib and cisplatin in renal cancer cells (80) and in head and neck squamous cell carcinoma (77), respectively. In vitro, EPO had a protective effect on radiation-treated MDA-MB-435 cells; however, EPO treatment alone or combined with chemotherapy or hypoxia did not influence cell survival. In vivo, EPO increased lung metastases in immunocompromised mice injected with MDA-MB-231 or MDA-MB-435 cells and treated with chemotherapy relative to mice treated with chemotherapy alone (90).

Very recently, Trošt et al. (55) confirmed the results of Arcasoy et al. (91) with positive response of breast cancer cells to EPO. Moreover, they demonstrated time- and concentration-dependent manner of EPO-induced MCF-7 proliferation and EGR1, FOS, and EPOR as transcription targets of the EPO-EPOR signaling loop (55). In this regard, Inbar et al. (92) discovered that EPO-driven EGR1 and c-FOS gene expression, as well as histone $\mathrm{H} 4$ acetylation in breast cancer cells were mediated via polyADP-ribosylation. EPO-induced breast cancer cell migration was blocked by the PARP inhibitor Veliparib (ABT-888), suggesting an essential role for polyADP-ribosylation in this process and suggesting a new cancer-associated anemia treatment modality with combined administration of EPO and PARP inhibitors (92).

Recent research revealed that EPO/EPOR contributes to the mechanism of trastuzumab resistance in breast cancer cell line SKBR3, and EPOR downregulation can reverse the resistance to trastuzumab. EPOR expression may be involved in tumor progression and proliferation in HER2-positive breast cancer 
(93). Indeed, EPO antagonized trastuzumab-induced therapeutic effects through JAK2-mediated activation of SRC and inactivation of PTEN protein, so combined therapy of HER2-positive cancer cells with EPO and trastuzumab reduced the response of these cells to trastuzumab both in vitro and in vivo. Furthermore, concurrent administration of EPO and trastuzumab correlated with shorter progression-free and overall survival in patients with HER2-positive metastatic breast cancer (57). The mechanism of EPO-EPOR and HER2 co-regulation in breast cancer was confirmed by miR-125b, which is downregulated in metastatic breast cancers and a significant positive correlation between EPOR and HER2 levels that are both targets of miR-125b was demonstrated (94).

Because of adverse tumor response and/or poorer survival in ESA-treated cancer patients, studies of EPO effects on cancer stem cells was initiated. Cao et al. (69) found that glioma stem cells (GSC) express higher levels of EPOR than matched non-stem glioma cells. They targeted EPOR expression in GSG with shRNA and reduced growth, survival, and neurosphere formation capacity, so confirmed the role for EPOR in GSC maintenance. A small molecule inhibitor of STAT3 led to reduced GSG growth and survival. EPO-EPOR signaling was also critical for survival in vivo, as targeting EPOR expression decreased GSC tumorigenic potential (69). Furthermore, Todaro et al. (71) showed that breast cancer stem-like cells (BCSC) isolated from patient tumors express the EPOR and respond to EPO treatment with increased proliferation and self-renewal. Importantly, EPO stimulation increased BCSC survival and resistance to chemotherapeutic agents, probably by EPO-activated AKT and ERK pathways and promoted metastatic progression of tumor xenografts in the presence and in the absence of chemotherapy treatment. These results suggest that EPO acts directly on BCSC by activating specific survival pathways, resulting in BCSC protection from chemotherapy and enhanced tumor progression (71). Moreover, EPO/EPOR promoted tumorigenesis in genetically engineered mouse models of breast cancer by activating JAK/STAT signaling in breast tumor-initiating cells (TICs) and promoted its self-renewal. EPO gene expression correlated with shortened relapse-free survival and pharmacologic JAK2 inhibition revealed a synergistic effect with chemotherapy in tumor growth inhibition in vivo (70).

\section{EPO AND TUMOR ANGIOGENESIS AND LYMPHANGIOGENESIS}

In 1990, Anagnostou et al. (9) found that EPO enhances the proliferation and migration of human umbilical vein endothelial cells and bovine adrenal capillary endothelial cells $(95,96)$ and demonstrated the presence of EPOR mRNA in human umbilical vein endothelial cells, as well as strong positive EPOR protein staining of the vascular endothelium in vivo (97). The presence of EPOR was also shown by Yamaji et al. (98), who suggested that brain capillary endothelial cells express not only an authentic form of EPOR (EPOR-F) but also a soluble one (EPOR-S) and that EPO acts directly on brain capillary endothelial cells as a competence factor. EPO signaling as a mitogen of endothelial cells was conducted via tyrosine phosphorylation of proteins including phosphorylation of transcription factor STAT-5, which is similar to that occurring in erythroid cells (99). Moreover, experiments performed in cultured vascular cells demonstrated that EPO robustly induced phosphorylation of STAT-5 in HUVEC cells, but only very weakly in smooth muscle cells (100). Results of our group revealed that conditioned media of EPO treated A2780 cells under hypoxic conditions induced significant STAT-5 phosphorylation, as well as proliferation of HUVEC cells. A new finding is the fact that prostimulatory effect of hypoxic A2780 media was partly mediated by EPO. Furthermore, EPO increased secretion of IL-4, IL-5, IL-6, IL-8, IL-10, IL-12, IL-13, GM-CSF, and IFN $\gamma$ by A2780 cells in hypoxic conditions (101).

An in vivo angiogenic potential of EPO was originally demonstrated by Yasuda et al. (102) who found that injection of EPO into the ovariectomized mouse uterine cavity promoted blood vessel formation of the endometrium. Similarly, Ribatti et al. (103) demonstrated that EPO induced a potent in vivo angiogenic response of the chick embryo chorioallantoic membrane. Furthermore, the role of EPO in physiological angiogenesis was described during wound healing and in the developing of mouse embryo (104, 105).

The study of Yasuda et al. (106) revealed that normal human cervix and endometrium, as well as ovary malignant tumors of female reproductive organs produce EPO and EPOR, and that the tumor cells themselves and capillary endothelial cells are sites responsive to the EPO signal. Yasuda et al. (107) proposed the presence of a paracrine or autocrine EPO-EPOR loop and its contribution to tumorigenesis in female reproductive organs based on the mitogenic action of EPO as well as on the finding that injection of soluble EPOR (EPOR-S) or EPO-monoclonal antibody into blocks of tumor specimens was followed by apoptosis of tumor cells and endothelial cells. Although some studies have not confirmed a direct stimulatory effect of EPO on tumor cells, there is ample evidence of this effect on endothelial cell proliferation and/or angiogenesis of tumors. In this regard, EPO xinduced angiogenesis in chemically induced murine hepatic tumors (108) and accelerated the growth of EPOR negative Lewis lung carcinoma cells by promoting tumor angiogenesis in vivo (109).

Interestingly, an EPO analog stimulated neovascularization in colorectal liver metastases of hepatectomized and nonhepatectomized mice (110). Moreover, Nico et al. (111) demonstrated that EPO secreted by glioma tumor cells affected glioma vascular endothelial cells and promoted angiogenesis in a paracrine manner. Specificity of the EPO effect was shown through an anti-EPO antibody, which was able to significantly inhibit the angiogenesis response. Despite the absence of melanoma growth stimulation in vivo, EPO increased vascular size in the xenografts. Indeed, EPO-induced angiogenesis in Matrigel plug assays, and neutralization of EPO secreted by melanoma cells resulted in decreased angiogenesis, which supports the role of EPO/EPOR in melanoma progression via angiogenesis stimulation (112). Even more interestingly, EPO accelerated the tumor growth of MMQ pituitary adenoma xenografts lacking EPOR via enhancement of angiogenesis in vivo, without a direct EPO effect on MMQ cells in vitro. EPO administration increased phosphorylation of JAK2, STAT3, and VEGF expression in HUVEC cells in vitro and in MMQ cell xenografts in vivo (113). The authors suggest that EPO administration may promote the growth of pituitary adenomas by enhancing angiogenesis through EPO-JAK2-STAT3-VEGF signaling pathway and should be used with caution in anemia patients 
Table 1 | Clinical trials with reported effects of ESA in cancer patients performed between 2009 and 2014

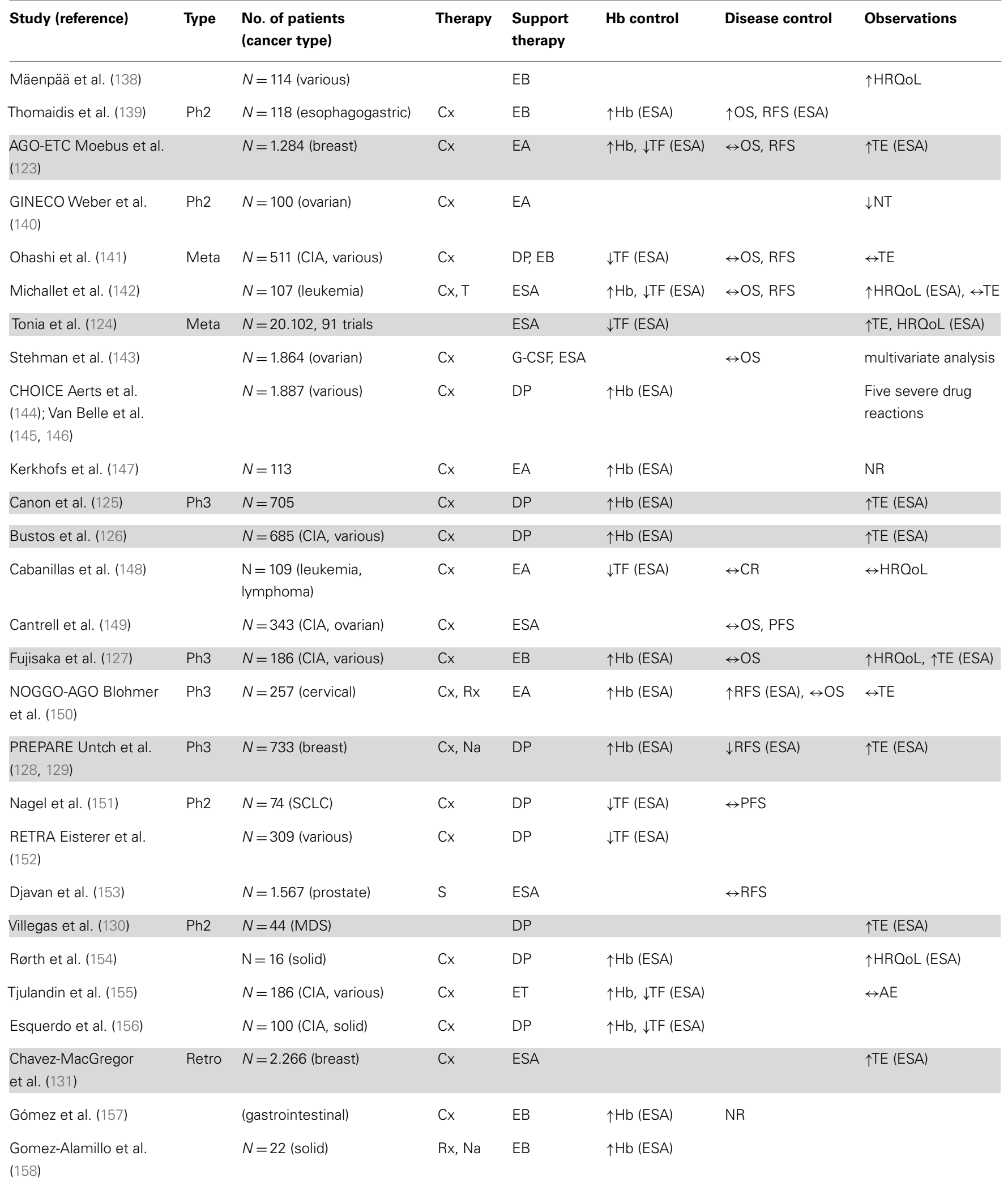


Table 1 | Continued

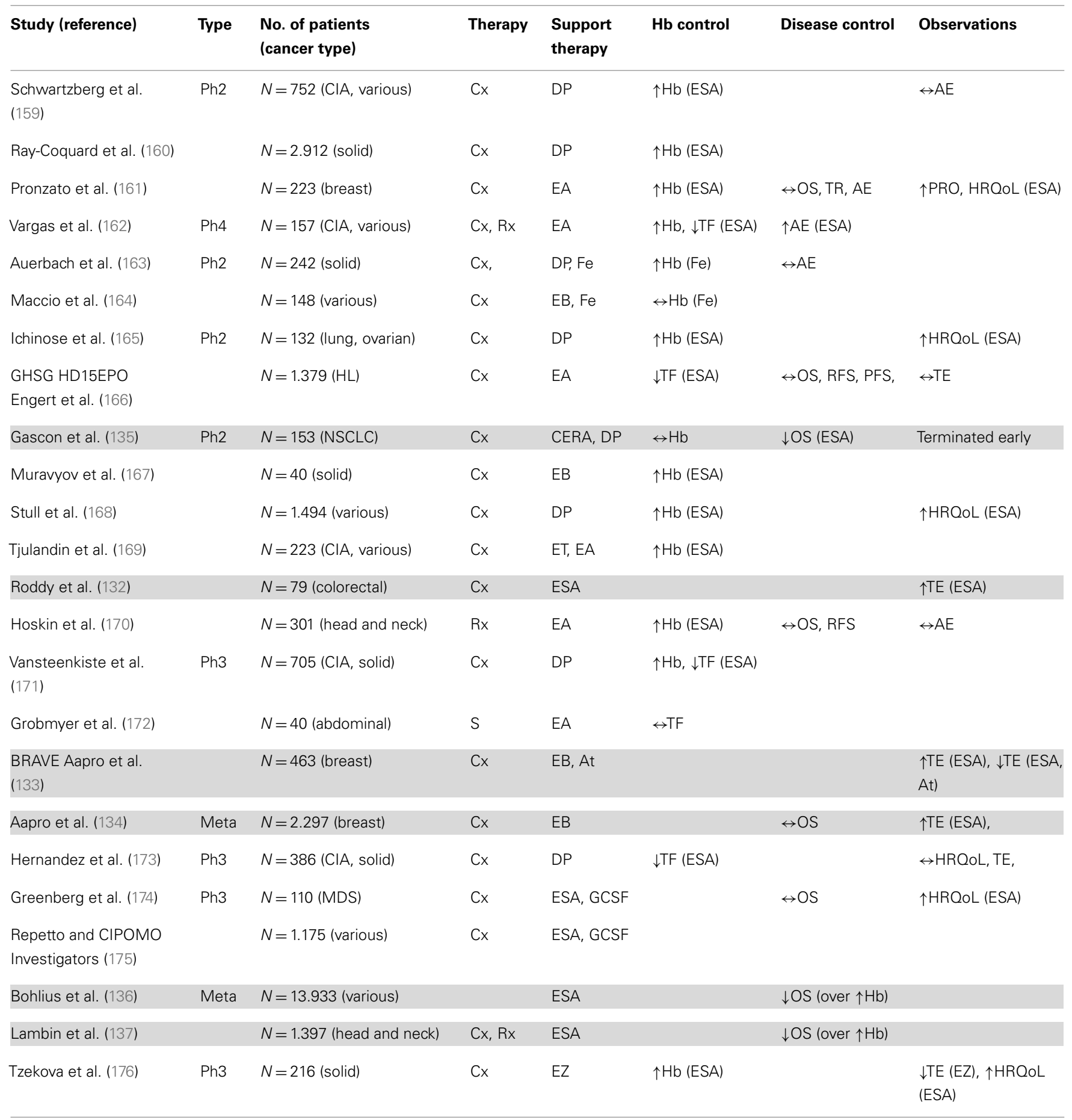

Study type: Meta, meta-analysis; Ph2-4, clinical study phase 2-4; Retro, retro-analysis. Disease/cancer type: CIA, chemotherapy-induced anemia; HL, Hodgkin's lymphoma; MDS, myelodysplastic syndrome; NSCLC, non-small-cell lung cancer; SCLC, small-cell lung cancer. Therapy: At, antithrombotic; CERA, continuous erythropoietin receptor activator; $C X$, chemotherapy; DP, darbepoetin; $E A$, epoetin alpha; $E B$, epoetin beta; ESA, erythropoiesis-stimulating agent; ET, epoetin theta; $E Z$, epoetin zeta; $F e$, iron supplementation; $N a$, neoadjuvant; $R x$, radiotherapy; $S$, surgery; $T F$, transfusion; $T$, transplantation. Disease control and observations: $A F$, adverse effects; CR, complete remission; DFS, disease-free survival; Hb, hemoglobin; HRQoL, health-related quality of life; NR, not reported; NT, neurotoxicity; OS, overall survival; PFS, progression-free survival; PRO, patient-reported outcomes; RFS, relapse-free survival; TE, thrombotic events; TR, tumor response; $\uparrow / \downarrow / \leftrightarrow$, increased/decreased/no significant difference.

Studies with indicated negative effects are marked in gray. 
Table 2 | Clinical studies exploring prognostic significance of EPO and EPOR expression in cancer patients.

\begin{tabular}{|c|c|c|c|c|c|}
\hline Study (reference) & $\begin{array}{l}\text { No. of patients } \\
\text { (cancer type) }\end{array}$ & Therapy & $\begin{array}{l}\text { EPO expression } \\
\text { as PF (method) }\end{array}$ & $\begin{array}{l}\text { EPOR expression } \\
\text { as PF (method) }\end{array}$ & Other observations \\
\hline Seibold et al. (178) & $\begin{array}{l}N=114 \text { (head and } \\
\text { neck SCC) }\end{array}$ & $\mathrm{S}, \mathrm{Rx}$ & $\begin{array}{l}\text { IPF - no EPO: } \uparrow L R C, \\
\uparrow M F S, \uparrow O S\end{array}$ & IPF - no EPOR: $\uparrow$ OS & \\
\hline Lin et al. (180) & $N=256($ oral SCC $)$ & S & l & 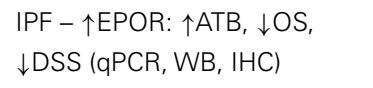 & \\
\hline Welsch et al. (177) & $N=104(\mathrm{PDAC})$ & & $\begin{array}{l}\text { IPF, } \uparrow s E P O: \downarrow O S(q P C R, \\
\text { ELISA, IHC) }\end{array}$ & (qPCR, IHC) & \\
\hline Gombos et al. (184) & $N=24($ colorectal $\mathrm{AC})$ & & 个EPO (IHC, qPCR, WB) & 个EPOR (IHC, qPCR, WB) & $\begin{array}{l}\uparrow E P O \text { and EPOR in } \\
\text { ischemia/necrosis }\end{array}$ \\
\hline Volgger et al. (181) & $N=107$ (breast) & ESA & l & $\begin{array}{l}\uparrow E P O R: \uparrow E R \text { and } \uparrow P R, \uparrow C R R, \\
\leftrightarrow O S(I H C, q P C R, W B)\end{array}$ & \\
\hline Xu et al. (186) & $\begin{array}{l}N=96 \text { (prostate: } \mathrm{PCa} \\
\text { PIN, BPH) }\end{array}$ & & $\uparrow E P O(B P H)(I H C)$ & 个EPOR (PCa, PIN) (IHC) & \\
\hline Liang et al. (57) & $N=55 / 37$ (breast) & TZ, ESA & l & $\begin{array}{l}\uparrow E P O R \text { and } \uparrow H E R 2: \downarrow T R \text { to } \\
T Z, \downarrow P F S, \downarrow O S(I H C)\end{array}$ & \\
\hline $\begin{array}{l}\text { Mirmoham-medsadegh } \\
\text { et al. (187) }\end{array}$ & $N=20$ (melanoma) & & l & $\uparrow E P O R(q P C R, I H C, W B)$ & \\
\hline Miller et al. (73) & $N=159$ (various) & ESA & (qPCR) & $\begin{array}{l}\leftrightarrow P F S, \uparrow E P O R: \downarrow P F S \text { in } \\
\text { unresected } T \text { (qPCR) }\end{array}$ & JAK2, HSP70 \\
\hline Küster et al. (183) & $N=131$ (meningioma) & & l & $\begin{array}{l}\downarrow E P O R: \uparrow C R R(I H C, q P C R, \\
\text { WB) }\end{array}$ & $\begin{array}{l}\text { EPOR-F, EPOR-T, } \\
\text { EPOR-S }\end{array}$ \\
\hline
\end{tabular}

Disease/cancer type: $B P H$, benign prostatic hyperplasia; CPT, choroid plexus tumors (glioma, meningioma); ER+, estrogen receptor positive; GAC, gastric adenocarcinoma; NSCLC, non-small-cell lung cancer; PR+, progesterone receptor positive; SCC, squamous cell carcinoma; PCa, prostate carcinoma; PDAC, pancreatic ductal adenocarcinoma; PIN, prostate intraepithelial neoplasia. Therapy: ESA, erythropoiesis-stimulating agent; $R x$, radiotherapy; $S$, surgery; TAM, tamoxifen; TZ, trastuzumab. Prognostic factor and observations: ATB, aggressive tumor behavior (TNM stage, T and N classification); CRR, cancer recurrence rate; DSS, disease-specific survival; IPF, independent prognostic factor; $L R C$, loco-regional control; $M D$, microvessel density; MFS, metastases-free survival; OS, overall survival; PF, prognostic factor; PFS, progression-free survival; sEPO, serum EPO; TR, tumor response; $\uparrow / \downarrow / \leftrightarrow$, increased/decreased/no significant difference. Methods: IHC, immunohistochemistry; qPCR, quantitative $P C R ; W B$, Western blotting.

bearing pituitary adenoma due to its potential deleterious effects (113). On the contrary, very recently Pascual et al. (114) found that preoperative administration of EPO stimulates tumor recurrence in an animal model of colon cancer, but no evidence of increased angiogenesis or enhanced-cell proliferation as possible mechanisms of EPO-induced recurrence was seen. Importantly,
$\mathrm{EPO} / \mathrm{EPOR}$ levels correlated well with angiogenesis and progression of patients with hepatocellular carcinoma, neuroblastoma, squamous cell carcinoma of the tongue, melanoma, and gastric adenocarcinoma (115-120).

The lymph node as a new target of EPO was presented by Lee et al. (121) They showed that EPO can stimulate both lymph node 
lymphangiogenesis and nodal metastasis by increased migration, capillary-like tube formation, and dose- and time-dependent proliferation of human lymphatic endothelial cells in tumor-bearing animals. Intraperitoneal administration of EPO induced AKT and ERK1/2 signalization followed by peritoneal lymphangiogenesis stimulation. Furthermore, systemic treatment of EPO increased infiltration of $\mathrm{CD} 11 \mathrm{~b}(+)$ macrophages in tumor-draining lymph nodes and increased VEGF-C expression in lymph node-derived $\mathrm{CD} 11 \mathrm{~b}(+)$ macrophages, as well as in bone marrow-derived macrophages in a dose- and time-dependent manner (121).

According to McKinney and Arcasoy (122), there are two potential mechanisms by which rHuEPO therapy may promote tumor progression and reduce survival in some cancer patients: (1) rHuEPO therapy may exert local effects in tumors, acting directly on tumor cells or other cell types in the tumor microenvironment, such as the vascular endothelium and tumor-associated macrophages or (2) rHuEPO may cause systemic effects that indirectly alter tumor biology in an unfavorable manner or directly give rise to specific systemic toxicities that impair survival. In this regard, elevated hemoglobin, increased viscosity, platelet activation, endothelial progenitor mobilization, immunomodulatory effects, and others could play significant roles. We add a third potential mechanism and this is direct effect of EPO on cancer stem and/or TICs, which could explain enhanced tumor progression and poor survival of some cancer patients treated with EPO.

\section{EPO (ESA) AND CLINICAL STUDIES}

Several clinical trials have addressed the effects of one of the EPO/ESA treatments on disease control in cancer patients on cotemporal anti-cancer therapy, such as chemotherapy, radiotherapy, neoadjuvant therapy, and surgery. Such EPO/ESA treatments are long termed and rarely single dosed. The review of clinical trials performed between 2009 and 2014 is presented in Table 1, being an update of review by Szenajch et al. (13). Some of the studies indicate a negative outcome (marked in gray). Most of the reported negative effects are due to increased thrombotic events, a complication driven by an increased number of RBC (123-134). However, some of the studies also indicate a reduced recurrence free survival and overall survival $(128,129,135-137)$. Negative effects on overall survival were already shown previously by several studies, reviewed by Szenajch et al. (13).

Clinical studies exploring the prognostic significance of EPO and EPOR expression in cancer patients have also been explored and are listed in Table 2. Several studies indicated increased EPO expression as prognostic factor for reduced overall survival $(120,177)$ or vice versa, no EPO expression as prognostic factor for increased overall survival $(178,179)$. Furthermore, increased EPOR expression was identified as prognostic factor for reduced overall survival, more aggressive tumor behavior, and progressionfree survival (57, 73, 120, 180-182). Increased EPOR expression was also linked to reduced response to anti-cancer treatment (56, 57). While no or reduced EPOR expression was identified as prognostic factor for increased overall survival (178) and in contrast, also to increased cancer recurrence rate (183). Most of these studies did not characterize the subtype of EPOR isoforms, which is crucial for interpretation of the data, as indicated by Küster et al. (183).
Based on discussed clinical studies, the adverse effect of $\mathrm{EPO} / \mathrm{ESA}$ in cancer patients during anti-cancer therapy could be related to chronic EPO treatment. Such EPO/ESA treatments are long termed and rarely single dosed. We suggest that the concurrent use of long-termed EPO/ESA and anti-cancer treatment is the main reason for EPO/ESA negative effects on response to anti-cancer therapy, overall survival, and disease recurrence. The mechanisms are still not well understood and more profound molecular and biochemical characterization is needed; however, they may be linked to one of the EPO/ESA mechanisms indicated in the previous chapter. EPOR, $\beta c R$, and EPHB4 were previously shown to be expressed in various tumors. We do speculate that one of these receptors and/or possible analogs of these receptors may be involved in the response of cancer cells to EPO/ESA therapy.

\section{CONCLUSION}

A plethora of scientific evidence demonstrates a growthpromoting, anti-apoptotic action of EPO and other ESAs on non-hematopoietic cells, both normal and malignant, and this is supported by numerous clinical observations showing adverse effects of EPO administration on the clinical management of tumor growth and progression. As anticipated just a few years ago (28), physicians who care for anemic cancer patients have been facing a dilemma, whether to treat the anemic patient with an ESA, thereby potentially increasing the risk of worsening the malignancy, or to withhold ESA treatment, with resultant patient fatigue, reduced physical activity, increased hypoxic stress, and reliance on transfusion therapy. Primary tumors are not yet EPOR typed (like breast cancers are assessed for ER/PR expression) though this idea should be considered. There has been much discussion of EPO use in cancer patients, and several professional and regulatory organizations and authorities have issued various guidances. Perhaps, the following "rule" used by several clinicians interviewed by one of the authors should be considered. If the cancer patient is being treated with curative intent, avoid the use of ESAs. If the treatment plan is more conservative or palliative, consider ESAs for anemia treatment, but proceed with great caution.

\section{AUTHOR CONTRIBUTIONS}

Nataša Debeljak outlined the work. All authors designed and drafted the work. Arthur J. Sytkowski critically revised the work. All authors approved final version of the work and agreed to be accountable for all aspects of the work.

\section{ACKNOWLEDGMENTS}

Nataša Debeljak was supported by the J3-0124 grant to ND and P10104 to Radovan Komel, both from the Slovenian Research Agency. Peter Solár was partly supported by Scientific Grant Agency of the Ministry of Education of the Slovak Republic under contract no. VEGA 1/0733/12. Arthur J. Sytkowski acknowledges the support of Quintiles Transnational where he is an executive director, hematology and oncology, in the Therapeutic Delivery Unit. The authors thank Klemen Španinger for contribution of Figure 1.

\section{REFERENCES}

1. Carnot P, Deflandre C. Sur l'activité hémopoiétique du sérum au cours de la régénération du sang. C R Acad Sci Paris (1906) 143:384-435. 
2. Erslev A. Humoral regulation of red cell production. Blood (1953) 8(4):349-57.

3. Miyake T, Kung CK, Goldwasser E. Purification of human erythropoietin. J Biol Chem (1977) 252(15):5558-64.

4. Jacobs K, Shoemaker C, Rudersdorf R, Neill SD, Kaufman RJ, Mufson A, et al. Isolation and characterization of genomic and cDNA clones of human erythropoietin. Nature (1985) 313(6005):806-10. doi:10.1038/313806a0

5. Lin FK, Suggs S, Lin CH, Browne JK, Smalling R, Egrie JC, et al. Cloning and expression of the human erythropoietin gene. Proc Natl Acad Sci U S A (1985) 82(22):7580-4. doi:10.1073/pnas.82.22.7580

6. Eschbach JW, Egrie JC, Downing MR, Browne JK, Adamson JW. Correction of the anemia of end-stage renal disease with recombinant human erythropoietin. Results of a combined phase I and II clinical trial. N Engl J Med (1987) 316(2):73-8. doi:10.1056/NEJM198701083160203

7. Glaspy J, Bukowski R, Steinberg D, Taylor C, Tchekmedyian S, Vadhan-Raj S. Impact of therapy with epoetin alfa on clinical outcomes in patients with nonmyeloid malignancies during cancer chemotherapy in community oncology practice Procrit Study Group. J Clin Oncol (1997) 15(3):1218-34.

8. Debeljak N, Sytkowski AJ. Erythropoietin and erythropoiesis stimulating agents. Drug Test Anal (2012) 4(11):805-12. doi:10.1002/dta.1341

9. Anagnostou A, Lee ES, Kessimian N, Levinson R, Steiner M. Erythropoietin has a mitogenic and positive chemotactic effect on endothelial cells. Proc Natl Acad Sci U S A (1990) 87(15):5978-82. doi:10.1073/pnas.87.15.5978

10. Digicaylioglu M, Bichet S, Marti HH, Wenger RH, Rivas LA, Bauer C, et al. Localization of specific erythropoietin binding sites in defined areas of the mouse brain. Proc Natl Acad Sci U S A (1995) 92(9):3717-20. doi:10.1073/ pnas.92.9.3717

11. Jelkmann W, Wagner K. Beneficial and ominous aspects of the pleiotropic action of erythropoietin. Ann Hematol (2004) 83(11):673-86. doi:10.1007/ s00277-004-0911-6

12. Maiese K, Li F, Chong ZZ. New avenues of exploration for erythropoietin. JAMA (2005) 293(1):90-5. doi:10.1001/jama.293.1.90

13. Szenajch J, Wcislo G, Jeong JY, Szczylik C, Feldman L. The role of erythropoietin and its receptor in growth, survival and therapeutic response of human tumor cells from clinic to bench - a critical review. Biochim Biophys Acta (2010) 1806(1):82-95. doi:10.1016/j.bbcan.2010.04.002

14. Powell JS, Berkner KL, Lebo RV, Adamson JW. Human erythropoietin gene: high level expression in stably transfected mammalian cells and chromosome localization. Proc Natl Acad Sci U S A (1986) 83(17):6465-9. doi:10.1073/pnas. 83.17.6465

15. Watkins PC, Eddy R, Hoffman N, Stanislovitis P, Beck AK, Galli J, et al. Regional assignment of the erythropoietin gene to human chromosome region 7pterq22. Cytogenet Cell Genet (1986) 42(4):214-8. doi:10.1159/000132281

16. Jelkmann W. Control of erythropoietin gene expression and its use in medicine. Methods Enzymol (2007) 435:179-97. doi:10.1016/S0076-6879(07)35010-6

17. Stockmann C, Fandrey J. Hypoxia-induced erythropoietin production: a paradigm for oxygen-regulated gene expression. Clin Exp Pharmacol Physiol (2006) 33(10):968-79. doi:10.1111/j.1440-1681.2006.04474.x

18. Rahbek-Nielsen H, Roepstorff P, Reischl H, Wozny M, Koll H, Haselbeck A. Glycopeptide profiling of human urinary erythropoietin by matrixassisted laser desorption/ionization mass spectrometry. J Mass Spectrom (1997) 32(9):948-58. doi:10.1002/(SICI)1096-9888(199709)32:9<948::AIDJMS551>3.0.CO;2-C

19. Lai PH, Everett R, Wang FF, Arakawa T, Goldwasser E. Structural characterization of human erythropoietin. J Biol Chem (1986) 261(7):3116-21.

20. Romanowski RR, Sytkowski AJ. The molecular structure of human erythropoietin. Hematol Oncol Clin North Am (1994) 8(5):885-94.

21. Delorme E, Lorenzini T, Giffin J, Martin F, Jacobsen F, Boone T, et al. Role of glycosylation on the secretion and biological activity of erythropoietin. Biochemistry (1992) 31(41):9871-6. doi:10.1021/bi00156a003

22. Dube S, Fisher JW, Powell JS. Glycosylation at specific sites of erythropoietin is essential for biosynthesis, secretion, and biological function. J Biol Chem (1988) 263(33):17516-21.

23. Sytkowski AJ, Feldman L, Zurbuch DJ. Biological activity and structural stability of N-deglycosylated recombinant human erythropoietin. Biochem Biophys Res Commun (1991) 176(2):698-704. doi:10.1016/S0006-291X(05)80240-2

24. Bachmann S, Le Hir M, Eckardt KU. Co-localization of erythropoietin mRNA and ecto-5'-nucleotidase immunoreactivity in peritubular cells of rat renal cortex indicates that fibroblasts produce erythropoietin. J Histochem Cytochem (1993) 41(3):335-41. doi:10.1177/41.3.8429197

25. Maxwell PH, Ferguson DJ, Nicholls LG, Iredale JP, Pugh CW, Johnson MH, et al. Sites of erythropoietin production. Kidney Int (1997) 51(2):393-401. doi:10.1038/ki.1997.52

26. Juul SE, Yachnis AT, Christensen RD. Tissue distribution of erythropoietin and erythropoietin receptor in the developing human fetus. Early Hum Dev (1998) 52(3):235-49. doi:10.1016/S0378-3782(98)00030-9

27. Sytkowski AJ. Erythropoietin: Blood, Brain and Beyond. Weinheim: Wiley-VCH (2004).

28. Sytkowski AJ. Does erythropoietin have a dark side? Epo signaling and cancer cells. Sci STKE (2007) 2007(395):e38. doi:10.1126/stke.3952007pe38

29. Recny MA, Scoble HA, Kim Y. Structural characterization of natural human urinary and recombinant DNA-derived erythropoietin. Identification of desarginine 166 erythropoietin. J Biol Chem (1987) 262(35):17156-63.

30. Spaninger K, Borštnar S, Matos E, Možina B, Sytkowski AJ, Komel R, et al. Report on isoelectric focusing trial of erythropoietin profiling in two cancer patients during chemotherapy and darbepoetin treatment. Acta Chim Slov (2011) 58(1):139-43.

31. Lasne F, Martin L, Crepin N, de Ceaurriz J. Detection of isoelectric profiles of erythropoietin in urine: differentiation of natural and administered recombinant hormones. Anal Biochem (2002) 311(2):119-26. doi:10.1016/S00032697(02)00407-4

32. Lasne F, Thioulouse J, Martin L, de Ceaurriz J. Detection of recombinant human erythropoietin in urine for doping analysis: interpretation of isoelectric profiles by discriminant analysis. Electrophoresis (2007) 28(12):1875-81. doi:10.1002/elps.200600363

33. Philo JS, Aoki KH, Arakawa T, Narhi LO, Wen J. Dimerization of the extracellular domain of the erythropoietin (EPO) receptor by EPO: one highaffinity and one low-affinity interaction. Biochemistry (1996) 35(5):1681-91. doi:10.1021/bi9524272

34. Debeljak N, Sytkowski AJ. EpoR: Basic Sequence: Mouse. UCSD Nature Molecule Pages. (2007). doi:10.1038/mp.a000863.01

35. Brines M, Grasso G, Fiordaliso F, Sfacteria A, Ghezzi P, Fratelli M, et al. Erythropoietin mediates tissue protection through an erythropoietin and common beta-subunit heteroreceptor. Proc Natl Acad Sci U S A (2004) 101(41):14907-12. doi:10.1073/pnas.0406491101

36. Jackson DB, Stein M, Voss H, Brock S. Tissue protective erythropoietin receptor (nepor) and methods of use. European Patent Application EP 2492355 A1 (2012).

37. Penny LA, Forget BG. Genomic organization of the human erythropoietin receptor gene. Genomics (1991) 11(4):974-80. doi:10.1016/0888-7543(91) 90022-7

38. Jones SS, D’Andrea AD, Haines LL, Wong GG. Human erythropoietin receptor: cloning, expression, and biologic characterization. Blood (1990) 76(1):31-5.

39. Winkelmann JC, Penny LA, Deaven LL, Forget BG, Jenkins RB. The gene for the human erythropoietin receptor: analysis of the coding sequence and assignment to chromosome 19p. Blood (1990) 76(1):24-30.

40. Arcasoy MO, Jiang X, Haroon ZA. Expression of erythropoietin receptor splice variants in human cancer. Biochem Biophys Res Commun (2003) 307(4):999-1007. doi:10.1016/S0006-291X(03)01303-2

41. Harris KW, Winkelmann JC. Enzyme-linked immunosorbent assay detects a potential soluble form of the erythropoietin receptor in human plasma. Am J Hematol (1996) 52(1):8-13. doi:10.1002/(SICI) 1096-8652(199605)52:1<8: :AID-AJH2>3.3.CO;2-O

42. Sinclair AM, Todd MD, Forsythe K, Knox SJ, Elliott S, Begley CG. Expression and function of erythropoietin receptors in tumors: implications for the use of erythropoiesis-stimulating agents in cancer patients. Cancer (2007) 110(3):477-88. doi:10.1002/cncr.22832

43. Bazan JF. Haemopoietic receptors and helical cytokines. Immunol Today (1990) 11(10):350-4. doi:10.1016/0167-5699(90)90139-Z

44. Bailey SC, Feldman L, Romanowski RR, Davis KL, Sytkowski AJ. Antipeptide antibodies as probes of the recombinant and endogenous murine erythropoietin receptors. Exp Hematol (1993) 21(12):1535-43.

45. Hosoi S, Miyaji H, Satoh M, Kurimoto T, Mihara A, Fujiyoshi N, et al. Optimization of cell culture conditions for production of biologically active proteins. Cytotechnology (1991) 5(Suppl 2):17-34. doi:10.1007/BF00573878 
46. McCaffery PJ, Fraser JK, Lin FK, Berridge MV. Subunit structure of the erythropoietin receptor. J Biol Chem (1989) 264(18):10507-12.

47. Brines M, Cerami A. Emerging biological roles for erythropoietin in the nervous system. Nat Rev Neurosci (2005) 6(6):484-94. doi:10.1038/nrn1687

48. Brines M, Cerami A. The receptor that tames the innate immune response. $\mathrm{Mol}$ Med (2012) 18:486-96. doi:10.2119/molmed.2011.00414

49. Brines M, Patel NS, Villa P, Brines C, Mennini T, De Paola M, et al. Nonerythropoietic, tissue-protective peptides derived from the tertiary structure of erythropoietin. Proc Natl Acad Sci U S A (2008) 105(31):10925-30. doi:10.1073/pnas.0805594105

50. Ghezzi P, Brines M. Erythropoietin as an antiapoptotic, tissue-protective cytokine. Cell Death Differ (2004) 11(Suppl 1):S37-44. doi:10.1038/sj.cdd. 4401450

51. Pasquale EB. Eph receptor signalling casts a wide net on cell behaviour. Nat Rev Mol Cell Biol (2005) 6(6):462-75. doi:10.1038/nrm1690

52. Kumar SR, Singh J, Xia G, Krasnoperov V, Hassanieh L, Ley EJ, et al. Receptor tyrosine kinase EphB4 is a survival factor in breast cancer. Am J Pathol (2006) 169(1):279-93. doi:10.2353/ajpath.2006.050889

53. Noren NK, Pasquale EB. Paradoxes of the EphB4 receptor in cancer. Cancer Res (2007) 67(9):3994-7. doi:10.1158/0008-5472.CAN-07-0525

54. Pelekanou V, Kampa M, Kafousi M, Dambaki K, Darivianaki K, Vrekoussis T, et al. Erythropoietin and its receptor in breast cancer: correlation with steroid receptors and outcome. Cancer Epidemiol Biomarkers Prev (2007) 16(10):2016-23. doi:10.1158/1055-9965.EPI-06-1023

55. Trošt N, Hevir N, Rižner TL, Debeljak N. Correlation between erythropoietin receptor(s) and estrogen and progesterone receptor expression in different breast cancer cell lines. Int J Mol Med (2013) 31(3):717-25. doi:10.3892/ijmm. 2013.1231

56. Larsson AM, Jirström K, Fredlund E, Nilsson S, Rydén L, Landberg G, et al. Erythropoietin receptor expression and correlation to tamoxifen response and prognosis in breast cancer. Clin Cancer Res (2009) 15(17):5552-9. doi:10.1158/ 1078-0432.CCR-08-3014

57. Liang K, Esteva FJ, Albarracin C, Stemke-Hale K, Lu Y, Bianchini G, et al. Recombinant human erythropoietin antagonizes trastuzumab treatment of breast cancer cells via Jak2-mediated Src activation and PTEN inactivation. Cancer Cell (2010) 18(5):423-35. doi:10.1016/j.ccr.2010.10.025

58. Reinbothe S, Larsson AM, Vaapil M, Wigerup C, Sun J, Jögi A, et al. EPOindependent functional EPO receptor in breast cancer enhances estrogen receptor activity and promotes cell proliferation. Biochem Biophys Res Commun (2014) 445(1):163-9. doi:10.1016/j.bbrc.2014.01.165

59. Pelekanou V, Notas G, Sanidas E, Tsapis A, Castanas E, Kampa M. Testosterone membrane-initiated action in breast cancer cells: interaction with the androgen signaling pathway and EPOR. Mol Oncol (2010) 4(2):135-49. doi:10.1016/j.molonc.2010.01.004

60. Notas G, Kampa M, Pelekanou V, Castanas E. Interplay of estrogen receptors and GPR30 for the regulation of early membrane initiated transcriptional effects: a pharmacological approach. Steroids (2012) 77(10):943-50. doi:10.1016/j.steroids.2011.11.005

61. Arcasoy MO. The non-haematopoietic biological effects of erythropoietin. $\mathrm{Br}$ J Haematol (2008) 141(1):14-31. doi:10.1111/j.1365-2141.2008.07014.x

62. Mastromarino V, Musumeci MB, Conti E, Tocci G, Volpe M. Erythropoietin in cardiac disease: effective or harmful? J Cardiovasc Med (Hagerstown) (2013) 14(12):870-8. doi:10.2459/JCM.0b013e328362c6ae

63. Sorg H, Harder Y, Krueger C, Reimers K, Vogt PM. The nonhematopoietic effects of erythropoietin in skin regeneration and repair: from basic research to clinical use. Med Res Rev (2013) 33(3):637-64. doi:10.1002/med. 21259

64. Farrell F, Lee A. The erythropoietin receptor and its expression in tumor cells and other tissues. Oncologist (2004) 9(Suppl 5):18-30. doi:10.1634/ theoncologist.9-90005-18

65. Hardee ME, Arcasoy MO, Blackwell KL, Kirkpatrick JP, Dewhirst MW. Erythropoietin biology in cancer. Clin Cancer Res (2006) 12(2):332-9. doi:10. 1158/1078-0432.CCR-05-1771

66. Udupa KB. Functional significance of erythropoietin receptor on tumor cells. World J Gastroenterol (2006) 12(46):7460-2. doi:10.3748/wjg.v12.i46.7460

67. Jeong JY, Feldman L, Solar P, Szenajch J, Sytkowski AJ. Characterization of erythropoietin receptor and erythropoietin expression and function in human ovarian cancer cells. Int J Cancer (2008) 122(2):274-80. doi:10.1002/ ijc. 23068
68. Osterborg A, Aapro M, Cornes P, Haselbeck A, Hayward CR, Jelkmann W. Preclinical studies of erythropoietin receptor expression in tumour cells: impact on clinical use of erythropoietic proteins to correct cancer-related anaemia. Eur J Cancer (2007) 43(3):510-9. doi:10.1016/j.ejca.2006.10.012

69. Cao Y, Lathia JD, Eyler CE, Wu Q, Li Z, Wang H, et al. Erythropoietin receptor signaling through STAT3 is required for glioma stem cell maintenance. Genes Cancer (2010) 1(1):50-61. doi:10.1177/1947601909356352

70. Zhou B, Damrauer JS, Bailey ST, Hadzic T, Jeong Y, Clark K, et al. Erythropoietin promotes breast tumorigenesis through tumor-initiating cell self-renewal. J Clin Invest (2014) 124(2):553-63. doi:10.1172/JCI69804

71. Todaro M, Turdo A, Bartucci M, Iovino F, Dattilo R, Biffoni M, et al. Erythropoietin activates cell survival pathways in breast cancer stem-like cells to protect them from chemotherapy. Cancer Res (2013) 73(21):6393-400. doi:10.1158/0008-5472.CAN-13-0248

72. Um M, Gross AW, Lodish HF. A "classical” homodimeric erythropoietin receptor is essential for the antiapoptotic effects of erythropoietin on differentiated neuroblastoma SH-SY5Y and pheochromocytoma PC-12 cells. Cell Signal (2007) 19(3):634-45. doi:10.1016/j.cellsig.2006.08.014

73. Miller CP, Lowe KA, Valliant-Saunders K, Kaiser JF, Mattern D, Urban N, et al. Evaluating erythropoietin-associated tumor progression using archival tissues from a phase III clinical trial. Stem Cells (2009) 27(9):2353-61. doi: $10.1002 /$ stem. 156

74. Feldman L, Wang Y, Rhim JS, Bhattacharya N, Loda M, Sytkowski AJ. Erythropoietin stimulates growth and STAT5 phosphorylation in human prostate epithelial and prostate cancer cells. Prostate (2006) 66(2):135-45. doi:10.1002/ pros. 20310

75. Lai SY, Childs EE, Xi S, Coppelli FM, Gooding WE, Wells A, et al. Erythropoietin-mediated activation of JAK-STAT signaling contributes to cellular invasion in head and neck squamous cell carcinoma. Oncogene (2005) 24(27):4442-9. doi:10.1038/sj.onc.1208635

76. Westenfelder C, Baranowski RL. Erythropoietin stimulates proliferation of human renal carcinoma cells. Kidney Int (2000) 58(2):647-57. doi:10.1046/ j.1523-1755.2000.00211.x

77. Abhold E, Rahimy E, Wang-Rodriguez J, Blair KJ, Yu MA, Brumund KT, et al. Recombinant human erythropoietin promotes the acquisition of a malignant phenotype in head and neck squamous cell carcinoma cell lines in vitro. BMC Res Notes (2011) 4:553. doi:10.1186/1756-0500-4-553

78. Lopez TV, Lappin TR, Maxwell P, Shi Z, Lopez-Marure R, Aguilar C, et al. Autocrine/paracrine erythropoietin signalling promotes JAK/STATdependent proliferation of human cervical cancer cells. Int J Cancer (2011) 129(11):2566-76. doi:10.1002/ijc.25935

79. Jeong JY, Hoxhaj G, Socha AL, Sytkowski AJ, Feldman L. An erythropoietin autocrine/paracrine axis modulates the growth and survival of human prostate cancer cells. Mol Cancer Res (2009) 7(7):1150-7. doi:10.1158/1541-7786.MCR08-0243

80. Wu P, Zhang N, Wang X, Zhang C, Li T, Ning X, et al. The erythropoietin/erythropoietin receptor signaling pathway promotes growth and invasion abilities in human renal carcinoma cells. PLoS One (2012) 7(9):e45122. doi:10.1371/journal.pone.0045122

81. Solár P, Hrcková G, Varinská L, Solárová Z, Kriška J, Uhrínová I, et al. Location and the functionality of erythropoietin receptor(s) in A2780 cells. Oncol Rep (2012) 28(1):141-6. doi:10.3892/or.2012.1795

82. Miyake M, Goodison S, Lawton A, Zhang G, Gomes-Giacoia E, Rosser CJ. Erythropoietin is a JAK2 and ERK1/2 effector that can promote renal tumor cell proliferation under hypoxic conditions. J Hematol Oncol (2013) 6:65. doi:10.1186/1756-8722-6-65

83. Paragh G, Kumar SM, Rakosy Z, Choi SC, Xu X, Acs G. RNA interferencemediated inhibition of erythropoietin receptor expression suppresses tumor growth and invasiveness in A2780 human ovarian carcinoma cells. Am J Pathol (2009) 174(4):1504-14. doi:10.2353/ajpath.2009.080592

84. Selzer E, Wacheck V, Kodym R, Schlagbauer-Wadl H, Schlegel W, Pehamberger $\mathrm{H}$, et al. Erythropoietin receptor expression in human melanoma cells. Melanoma Res (2000) 10(5):421-6. doi:10.1097/00008390-200010000-00003

85. Shiozawa Y, McGee S, Pienta MJ, McGregor N, Jung Y, Yumoto K, et al. Erythropoietin supports the survival of prostate cancer, but not growth and bone metastasis. J Cell Biochem (2013) 114(11):2471-8. doi:10.1002/jcb.24592

86. Swift S, Ellison AR, Kassner P, McCaffery I, Rossi J, Sinclair AM, et al. Absence of functional EpoR expression in human tumor cell lines. Blood (2010) 115(21):4254-63. doi:10.1182/blood-2009-10-248674 
87. Pérès EA, Valable S, Guillamo JS, Marteau L, Bernaudin JF, Roussel S, et al. Targeting the erythropoietin receptor on glioma cells reduces tumour growth. Exp Cell Res (2011) 317(16):2321-32. doi:10.1016/j.yexcr.2011.06.011

88. Akiyama M, Kawano T, Mikami-Terao Y, Agawa-Ohta M, Yamada O, Ida H, et al. Erythropoietin activates telomerase through transcriptional and posttranscriptional regulation in human erythroleukemic JAS-REN-A cells. Leuk Res (2011) 35(3):416-8. doi:10.1016/j.leukres.2010.11.002

89. Aguilar C, Aguilar C, Lopez-Marure R, Jiménez-Sánchez A, Rocha-Zavaleta L. Co-stimulation with stem cell factor and erythropoietin enhances migration of c-Kit expressing cervical cancer cells through the sustained activation of ERK1/2. Mol Med Rep (2014) 9(5):1895-902. doi:10.3892/mmr.2014.2044

90. Hedley BD, Chu JE, Ormond DG, Beausoleil MS, Boasie A, Allan AL, et al. Recombinant human erythropoietin in combination with chemotherapy increases breast cancer metastasis in preclinical mouse models. Clin Cancer Res (2011) 17(19):6151-62. doi:10.1158/1078-0432.CCR-10-3298

91. Arcasoy MO, Amin K, Karayal AF, Chou SC, Raleigh JA, Varia MA, et al. Functional significance of erythropoietin receptor expression in breast cancer. $L a b$ Invest (2002) 82(7):911-8. doi:10.1097/01.LAB.0000020415.72863.40

92. Inbar D, Cohen-Armon M, Neumann D. Erythropoietin-driven signalling and cell migration mediated by polyADP-ribosylation. Br J Cancer (2012) 107(8):1317-26. doi:10.1038/bjc.2012.395

93. Zhang C, Duan X, Xu L, Ye J, Zhao J, Liu Y. Erythropoietin receptor expression and its relationship with trastuzumab response and resistance in HER2positive breast cancer cells. Breast Cancer Res Treat (2012) 136(3):739-48. doi:10.1007/s10549-012-2316-x

94. Ferracin M, Bassi C, Pedriali M, Pagotto S, D’Abundo L, Zagatti B, et al. miR125b targets erythropoietin and its receptor and their expression correlates with metastatic potential and ERBB2/HER2 expression. Mol Cancer (2013) 12(1):130. doi:10.1186/1476-4598-12-130

95. Carlini RG, Dusso AS, Obialo CI, Alvarez UM, Rothstein M. Recombinant human erythropoietin ( $\mathrm{rHuEPO}$ ) increases endothelin-1 release by endothelial cells. Kidney Int (1993) 43(5):1010-4. doi:10.1038/ki.1993.142

96. Carlini RG, Reyes AA, Rothstein M. Recombinant human erythropoietin stimulates angiogenesis in vitro. Kidney Int (1995) 47(3):740-5. doi:10.1038/ki. 1995.113

97. Anagnostou A, Liu Z, Steiner M, Chin K, Lee ES, Kessimian N, et al. Erythropoietin receptor mRNA expression in human endothelial cells. Proc Natl Acad Sci US A (1994) 91(9):3974-8. doi:10.1073/pnas.91.9.3974

98. Yamaji R, Okada T, Moriya M, Naito M, Tsuruo T, Miyatake K, et al. Brain capillary endothelial cells express two forms of erythropoietin receptor mRNA. Eur J Biochem (1996) 239(2):494-500. doi:10.1111/j.1432-1033.1996. 0494u.x

99. Haller H, Christel C, Dannenberg L, Thiele P, Lindschau C, Luft FC. Signal transduction of erythropoietin in endothelial cells. Kidney Int (1996) 50(2):481-8. doi:10.1038/ki.1996.339

100. Janmaat ML, Heerkens JL, de Bruin AM, Klous A, de Waard V, de Vries CJ. Erythropoietin accelerates smooth muscle cell-rich vascular lesion formation in mice through endothelial cell activation involving enhanced PDGF-BB release. Blood (2010) 115(7):1453-60. doi:10.1182/blood-2009-07-230870

101. Kriška J, Solár P, Varinská L, Solárová Z, Kimáková P, Mojžiš J, et al. Human erythropoietin increases the pro-angiogenic potential of A2780 ovarian adenocarcinoma cells under hypoxic conditions. Oncol Rep (2013) 30(3):1455-62. doi:10.3892/or.2013.2566

102. Yasuda Y, Masuda S, Chikuma M, Inoue K, Nagao M, Sasaki R. Estrogendependent production of erythropoietin in uterus and its implication in uterine angiogenesis. J Biol Chem (1998) 273(39):25381-7. doi:10.1074/jbc.273.39. 25381

103. Ribatti D, Presta M, Vacca A, Ria R, Giuliani R, Dell'Era P, et al. Human erythropoietin induces a pro-angiogenic phenotype in cultured endothelial cells and stimulates neovascularization in vivo. Blood (1999) 93(8):2627-36.

104. Haroon ZA, Amin K, Jiang X, Arcasoy MO. A novel role for erythropoietin during fibrin-induced wound-healing response. Am J Pathol (2003) 163(3):993-1000. doi:10.1016/S0002-9440(10)63459-1

105. Kertesz N, Wu J, Chen TH, Sucov HM, Wu H. The role of erythropoietin in regulating angiogenesis. Dev Biol (2004) 276(1):101-10. doi:10.1016/j.ydbio. 2004.08.025

106. Yasuda Y, Fujita Y, Musha T, Tanaka H, Shiokawa S, Nakamatsu K, et al. Expression of erythropoietin in human female reproductive organs. Ital J Anat Embryol (2001) 106(2 Suppl 2):215-22.
107. Yasuda Y, Fujita Y, Masuda S, Musha T, Ueda K, Tanaka H, et al. Erythropoietin is involved in growth and angiogenesis in malignant tumours of female reproductive organs. Carcinogenesis (2002) 23(11):1797-805. doi:10.1093/carcin/23. 11.1797

108. Nakamatsu K, Nishimura Y, Suzuki M, Kanamori S, Maenishi O, Yasuda Y. Erythropoietin/erythropoietin-receptor system as an angiogenic factor in chemically induced murine hepatic tumors. Int J Clin Oncol (2004) 9(3):184-8. doi:10.1007/s10147-004-0399-z

109. Okazaki T, Ebihara S, Asada M, Yamanda S, Niu K, Arai H. Erythropoietin promotes the growth of tumors lacking its receptor and decreases survival of tumor-bearing mice by enhancing angiogenesis. Neoplasia (2008) 10(9):932-9.

110. Rupertus K, Senger S, Menger MD, Schilling MK, Kollmar O. Darbepoetinalpha promotes neovascularization and cell proliferation in established colorectal liver metastases. J Surg Res (2012) 176(2):517-23. doi:10.1016/j.jss. 2011.09.062

111. Nico B, Annese T, Guidolin D, Finato N, Crivellato E, Ribatti D. Epo is involved in angiogenesis in human glioma. J Neurooncol (2011) 102(1):51-8. doi:10.1007/s11060-010-0294-6

112. Kumar SM, Zhang G, Bastian BC, Arcasoy MO, Karande P, Pushparajan A, et al. Erythropoietin receptor contributes to melanoma cell survival in vivo. Oncogene (2012) 31(13):1649-60. doi:10.1038/onc.2011.366

113. Yang J, Xiao Z, Li T, Gu X, Fan B. Erythropoietin promotes the growth of pituitary adenomas by enhancing angiogenesis. Int J Oncol (2012) 40(4):1230-7. doi:10.3892/ijo.2011.1261

114. Pascual M, Bohle B, Alonso S, Mayol X, Salvans S, Grande L, et al. Preoperative administration of erythropoietin stimulates tumor recurrence after surgical excision of colon cancer in mice by a vascular endothelial growth factorindependent mechanism. J Surg Res (2013) 183(1):270-7. doi:10.1016/j.jss. 2012.12.041

115. Ribatti D. Erythropoietin and tumor angiogenesis. Stem Cells Dev (2010) 19(1):1-4. doi:10.1089/scd.2009.0402

116. Ribatti D, Marzullo A, Gentile A, Longo V, Nico B, Vacca A, et al. Erythropoietin/erythropoietin-receptor system is involved in angiogenesis in human hepatocellular carcinoma. Histopathology (2007) 50(5):591-6. doi:10. $1111 /$ j.1365-2559.2007.02654.x

117. Ribatti D, Nico B, Perra MT, Longo V, Maxia C, Annese T, et al. Erythropoietin is involved in angiogenesis in human primary melanoma. Int J Exp Pathol (2010) 91(6):495-9. doi:10.1111/j.1365-2613.2010.00731.x

118. Ribatti D, Poliani PL, Longo V, Mangieri D, Nico B, Vacca A. Erythropoietin/erythropoietin receptor system is involved in angiogenesis in human neuroblastoma. Histopathology (2007) 50(5):636-41. doi:10.1111/j.1365-2559. 2007.02654.x

119. Li HG, Li JS, Chen WL, Wang L, Wu DH, Lin ZY. Prognostic significance of erythropoietin and erythropoietin receptor in tongue squamous cell carcinoma. Br JOral Maxillofac Surg (2009) 47(6):470-5. doi:10.1016/j.bjoms.2009.06.001

120. Wang L, Li HG, Xia ZS, Wen JM, Lv J. Prognostic significance of erythropoietin and erythropoietin receptor in gastric adenocarcinoma. World J Gastroenterol (2011) 17(34):3933-40. doi:10.3748/wjg.v17.i34.3933

121. Lee AS, Kim DH, Lee JE, Jung YJ, Kang KP, Lee S, et al. Erythropoietin induces lymph node lymphangiogenesis and lymph node tumor metastasis. Cancer Res (2011) 71(13):4506-17. doi:10.1158/0008-5472.CAN-10-3787

122. McKinney M, Arcasoy MO. Erythropoietin for oncology supportive care. Exp Cell Res (2011) 317(9):1246-54. doi:10.1016/j.yexcr.2011.03.003

123. Moebus V, Jackisch C, Schneeweiss A, Huober J, Lueck HJ, du Bois A, et al. Adding epoetin alfa to intense dose-dense adjuvant chemotherapy for breast cancer: randomized clinical trial. J Natl Cancer Inst (2013) 105(14):1018-26. doi:10.1093/jnci/djt145

124. Tonia T, Mettler A, Robert N, Schwarzer G, Seidenfeld J, Weingart O, et al. Erythropoietin or darbepoetin for patients with cancer. Cochrane Database Syst Rev (2012) 12:CD003407. doi:10.1002/14651858.CD003407.pub5

125. Canon JL, Vansteenkiste J, Hedenus M, Gascon P, Bokemeyer C, Ludwig H, et al. Transfusion risk in cancer patients with chemotherapy-induced anemia when initiating darbepoetin alfa therapy at a baseline hemoglobin level of $<9 \mathrm{~g} / \mathrm{dL}$ versus 9 to $<10 \mathrm{~g} / \mathrm{dL}$ versus $>/=10 \mathrm{~g} / \mathrm{dL}$ : an exploratory analysis of a phase 3 trial. Med Oncol (2012) 29(3):2291-9. doi:10.1007/s12032-011-0103-x

126. Bustos A, Álvarez R, Aramburo PM, Carabantes F, Díaz N, Florián J, et al. Evaluation of clinical use and effectiveness of darbepoetin alfa in cancer patients with chemotherapy-induced anemia. Curr Med Res Opin (2012) 28(1):57-67. doi:10.1185/03007995.2011.639352 
127. Fujisaka Y, Sugiyama T, Saito H, Nagase S, Kudoh S, Endo M, et al. Randomised, phase III trial of epoetin-beta to treat chemotherapy-induced anaemia according to the EU regulation. Br J Cancer (2011) 105(9):1267-72. doi:10.1038/bjc.2011.395

128. Untch M, Fasching PA, Konecny GE, von Koch F, Conrad U, Fett W, et al. PREPARE trial: a randomized phase III trial comparing preoperative, dose-dense, dose-intensified chemotherapy with epirubicin, paclitaxel and CMF versus a standard-dosed epirubicin/cyclophosphamide followed by paclitaxel \pm darbepoetin alfa in primary breast cancer - results at the time of surgery. Ann Oncol (2011) 22(9):1988-98. doi:10.1093/annonc/mdq709

129. Untch M, von Minckwitz G, Konecny GE, Conrad U, Fett W, Kurzeder C, et al. PREPARE trial: a randomized phase III trial comparing preoperative, dosedense, dose-intensified chemotherapy with epirubicin, paclitaxel, and CMF versus a standard-dosed epirubicin-cyclophosphamide followed by paclitaxel with or without darbepoetin alfa in primary breast cancer - outcome on prognosis. Ann Oncol (2011) 22(9):1999-2006. doi:10.1093/annonc/mdq713

130. Villegas A, Arrizabalaga B, Fernández-Lago C, Castro M, Mayans JR, GonzálezPorras JR, et al. Darbepoetin alfa for anemia in patients with low or intermediate-1 risk myelodysplastic syndromes and positive predictive factors of response. Curr Med Res Opin (2011) 27(5):951-60. doi:10.1185/03007995. 2011.561834

131. Chavez-MacGregor M, Zhao H, Fang S, Srokowski TP, Hortobagyi GN, Giordano SH. Complications associated with erythropoietin-stimulating agents in patients with metastatic breast cancer: a Surveillance, Epidemiology, and End Results-Medicare study. Cancer (2011) 117(16):3641-9. doi:10.1002/cncr. 25972

132. Roddy JV, Partridge SM, Rockey ML, Pruemer JM, Guo JJ, Desai SJ, et al. Thromboembolic events in patients with colorectal cancer receiving the combination of bevacizumab-based chemotherapy and erythropoietin stimulating agents. Am J Clin Oncol (2010) 33(1):36-42. doi:10.1097/COC. 0b013e31819cccaf

133. Aapro M, Van Erps J, MacDonald K, Soubeyran P, Muenzberg M, Turner M, et al. Managing cancer-related anaemia in congruence with the EORTC guidelines is an independent predictor of haemoglobin outcome: initial evidence from the RESPOND study. Eur J Cancer (2009) 45(1):8-11. doi:10.1016/j.ejca. 2008.09.036

134. Aapro M, Osterwalder B, Scherhag A, Burger HU. Epoetin-beta treatment in patients with cancer chemotherapy-induced anaemia: the impact of initial haemoglobin and target haemoglobin levels on survival, tumour progression and thromboembolic events. Br J Cancer (2009) 101(12):1961-71. doi:10.1038/sj.bjc.6605255

135. Gascon P, Pirker R, Del Mastro L, Durrwell L. Effects of CERA (continuous erythropoietin receptor activator) in patients with advanced non-small-cell lung cancer (NSCLC) receiving chemotherapy: results of a phase II study. Ann Oncol (2010) 21(10):2029-39. doi:10.1093/annonc/mdq073

136. Bohlius J, Schmidlin K, Brillant C, Schwarzer G, Trelle S, Seidenfeld J, et al. Recombinant human erythropoiesis-stimulating agents and mortality in patients with cancer: a meta-analysis of randomised trials. Lancet (2009) 373(9674):1532-42. doi:10.1016/S0140-6736(09)60502-X

137. Lambin P, Ramaekers BL, van Mastrigt GA, Van den Ende P, de Jong J, De Ruysscher DK, et al. Erythropoietin as an adjuvant treatment with (chemo) radiation therapy for head and neck cancer. Cochrane Database Syst Rev (2009) 138(3):CD006158. doi:10.1002/14651858.CD006158.pub2

138. Mäenpää J, Puistola U, Riska H, Sintonen H, Saarni O, Juvonen E, et al. Impact of epoetin-beta on anemia and health-related quality of life in cancer patients: a prospective observational study using the generic $15 \mathrm{D}$ instrument. Anticancer Res (2014) 34(5):2325-9.

139. Thomaidis T, Weinmann A, Sprinzl M, Kanzler S, Raedle J, Ebert M, et al. Erythropoietin treatment in chemotherapy-induced anemia in previously untreated advanced esophagogastric cancer patients. Int J Clin Oncol (2014) 19(2):288-96. doi:10.1007/s10147-013-0544-7

140. Weber B, Largillier R, Ray-Coquard I, Yazbek G, Meunier J, Alexandre J, et al. A potentially neuroprotective role for erythropoietin with paclitaxel treatment in ovarian cancer patients: a prospective phase II GINECO trial. Support Care Cancer (2013) 21(7):1947-54. doi:10.1007/s00520-013-1748-0

141. Ohashi Y, Uemura Y, Fujisaka Y, Sugiyama T, Ohmatsu H, Katsumata $\mathrm{N}$, et al. Meta-analysis of epoetin beta and darbepoetin alfa treatment for chemotherapy-induced anemia and mortality: individual patient data from Japanese randomized, placebo-controlled trials. Cancer Sci (2013) 104(4):481-5. doi:10.1111/cas.12105

142. Michallet M, Goldet K, Sobh M, Morisset S, Chelghoum Y, Thomas X, et al. Prospective study of erythropoietin use on quality of life and cost effectiveness in acute myeloid leukemia and allogeneic hematopoietic stem cell transplantation patients. Cancer (2013) 119(1):107-14. doi:10.1002/cncr.27686

143. Stehman FB, Brady MF, Thigpen JT, Rossi EC, Burger RA. Cytokine use and survival in the first-line treatment of ovarian cancer: a Gynecologic Oncology Group Study. Gynecol Oncol (2012) 127(3):495-501. doi:10.1016/j.ygyno. 2012.09.002

144. Aerts JG, Swieboda-Sadlej A, Karanikiotis C, Labourey JL, Galid A, Wheeler $\mathrm{T}$, et al. Use of darbepoetin alfa in European clinical practice for the management of chemotherapy-induced anaemia in four tumour types: final data from the CHOICE study. Curr Med Res Opin (2012) 28(7):1089-99. doi:10.1185/03007995.2012.698602

145. Van Belle S, Karanikiotis C, Labourey JL, Galid A, Wheeler T, Pujol B. Current practice of darbepoetin alfa in the management of haemoglobin levels in cancer patients undergoing chemotherapy - data from the CHOICE study. Curr Med Res Opin (2011) 27(5):987-94. doi:10.1185/03007995.2011.562493

146. Van Belle S, Swieboda-Sadlej A, Karanikiotis C, Labourey JL, Galid A, Wheeler $\mathrm{T}$, et al. A final analysis from the CHOICE study examining darbepoetin alfa use for chemotherapy-induced anaemia in current European clinical practice. Curr Med Res Opin (2012) 28(7):1079-87. doi:10.1185/03007995.2012.698601

147. Kerkhofs L, Boschetti G, Lugini A, Stanculeanu DL, Palomo AG. Use of biosimilar epoetin to increase hemoglobin levels in patients with chemotherapyinduced anemia: real-life clinical experience. Future Oncol (2012) 8(6):751-6. doi: $10.2217 /$ fon. 12.39

148. Cabanillas ME, Kantarjian H, Thomas DA, Mattiuzzi GN, Rytting ME, Bruera E, et al. Epoetin alpha decreases the number of erythrocyte transfusions in patients with acute lymphoblastic leukemia, lymphoblastic lymphoma, and Burkitt leukemia/lymphoma: results of a randomized clinical trial. Cancer (2012) 118(3):848-55. doi:10.1002/cncr.26341

149. Cantrell LA, Westin SN, Van Le L. The use of recombinant erythropoietin for the treatment of chemotherapy-induced anemia in patients with ovarian cancer does not affect progression-free or overall survival. Cancer (2011) 117(6):1220-6. doi:10.1002/cncr.25590

150. Blohmer JU, Paepke S, Sehouli J, Boehmer D, Kolben M, Würschmidt F, et al. Randomized phase III trial of sequential adjuvant chemoradiotherapy with or without erythropoietin alfa in patients with high-risk cervical cancer: results of the NOGGO-AGO intergroup study. J Clin Oncol (2011) 29(28):3791-7. doi:10.1200/JCO.2010.30.4899

151. Nagel S, Kellner O, Engel-Riedel W, Guetz S, Schumann C, Gieseler F, et al. Addition of darbepoetin alfa to dose-dense chemotherapy: results from a randomized phase II trial in small-cell lung cancer patients receiving carboplatin plus etoposide. Clin Lung Cancer (2011) 12(1):62-9. doi:10.3816/CLC.2011.n.009

152. Eisterer W, Hussl C, Erb H, Haslbauer F, Sormann S, Braun S, et al. RETRA: evaluating the transfusion rate with darbepoetin alfa 500 microg every 3 weeks in anaemic cancer patients receiving chemotherapy. Curr Med Res Opin (2011) 27(2):355-63. doi:10.1185/03007995.2010.542134

153. Djavan B, Laze J, Eckersberger E, Finkelstein J, Agalliu I, Lepor H. The shortterm use of erythropoetin-stimulating agents: impact on the biochemical recurrence of prostate cancer. BJU Int (2011) 108(10):1582-7. doi:10.1111/ j.1464-410X.2011.10173.x

154. Rørth M, Madsen KR, Burmølle SH, Midtgaard J, Andersen C, Nielsen B, et al. Effects of darbepoetin alfa with exercise in cancer patients undergoing chemotherapy: an explorative study. Scand J Med Sci Sports (2011) 21(3):369-77. doi:10.1111/j.1600-0838.2009.01066.x

155. Tjulandin SA, Bias P, Elsässer R, Gertz B, Kohler E, Buchner A. Epoetin theta with a new dosing schedule in anaemic cancer patients receiving nonplatinumbased chemotherapy: a randomised controlled trial. Arch Drug Inf (2011) 4(3):33-41. doi:10.1111/j.1753-5174.2011.00035.x

156. Esquerdo G, Llorca C, Cervera JM, Orts D, Juárez A, Carrato A. Effectiveness of darbepoetin alfa in a cohort of oncology patients with chemotherapy-induced anaemia. Relationship between variation in three fatigue-specific quality of life questionnaire scores and change in haemoglobin level. Clin Transl Oncol (2011) 13(5):341-7. doi:10.1007/s12094-011-0664-3

157. Gómez A, Salgado M, Valladares-Ayerbes M, Jorge M, Carballo A, Candamio S, et al. Efficacy of epoetin-beta 30,000 IU/week in correcting anaemia in patients 
with gastrointestinal tumours subjected to concomitant chemoradiotherapy. Clin Transl Oncol (2010) 12(12):843-8. doi:10.1007/s12094-010-0607-4

158. Gomez-Alamillo C, Fernández-Fresnedo G, Ortega F, Campistol JM, Gentil MA, Arias M, et al. Erythropoietin resistance as surrogate marker of graft and patient survival in renal transplantation: 3-year prospective multicenter study. Transplant Proc (2010) 42(8):2935-7. doi:10.1016/j.transproceed.2010. 07.043

159. Schwartzberg L, Burkes R, Mirtsching B, Rearden T, Silberstein P, Yee L, et al. Comparison of darbepoetin alfa dosed weekly $(\mathrm{QW})$ vs. extended dosing schedule (EDS) in the treatment of anemia in patients receiving multicycle chemotherapy in a randomized, phase 2, open-label trial. BMC Cancer (2010) 10:581. doi:10.1186/1471-2407-10-581

160. Ray-Coquard I, Laplaige P, Vey N, Asselain B, Urbieta M. A prospective, observational study describing the haematological response in patients undergoing chemotherapy treated by tri-weekly darbepoetin alfa for anaemia. Curr Med Res Opin (2010) 26(11):2653-60. doi:10.1185/03007995.2010.526099

161. Pronzato P, Cortesi E, van der Rijt CC, Bols A, Moreno-Nogueira JA, de Oliveira $\mathrm{CF}$, et al. Epoetin alfa improves anemia and anemia-related, patient-reported outcomes in patients with breast cancer receiving myelotoxic chemotherapy: results of a European, multicenter, randomized, controlled trial. Oncologist (2010) 15(9):935-43. doi:10.1634/theoncologist.2009-0279

162. Vargas A, Mendoza I, Uranga R, González A, Martínez L, Caballero I, et al. Efficacy and safety of iorEPOCIM for chemotherapy- or radiotherapy-induced anemia in pediatric cancer patients. MEDICC Rev (2010) 12(3):27-31.

163. Auerbach M, Silberstein PT, Webb RT, Averyanova S, Ciuleanu TE, Shao J, et al. Darbepoetin alfa 300 or 500 mug once every 3 weeks with or without intravenous iron in patients with chemotherapy-induced anemia. Am J Hematol (2010) 85(9):655-63. doi:10.1002/ajh.21779

164. Maccio A, Madeddu C, Gramignano G, Mulas C, Sanna E, Mantovani G, et al. Efficacy and safety of oral lactoferrin supplementation in combination with rHuEPO-beta for the treatment of anemia in advanced cancer patients undergoing chemotherapy: open-label, randomized controlled study. Oncologist (2010) 15(8):894-902. doi:10.1634/theoncologist.2010-0020

165. Ichinose Y, Seto T, Nishiwaki Y, Ohe Y, Yamada Y, Takeda K, et al. Randomized phase 2 dose-finding study of weekly administration of darbepoetin alpha in anemic patients with lung or ovarian cancer receiving multicycle platinum-containing chemotherapy. Jpn J Clin Oncol (2010) 40(6):521-9. doi:10.1093/jico/hyq017

166. Engert A, Josting A, Haverkamp H, Villalobos M, Lohri A, Sökler M, et al. Epoetin alfa in patients with advanced-stage Hodgkin's lymphoma: results of the randomized placebo-controlled GHSG HD15EPO trial. J Clin Oncol (2010) 28(13):2239-45. doi:10.1200/JCO.2009.25.1835

167. Muravyov AV, Cheporov SV, Kislov NV, Bulaeva SV, Maimistova AA. Comparative efficiency and hemorheological consequences of hemotransfusion and epoetin therapy in anemic cancer patients. Clin Hemorheol Microcirc (2010) 44(2):115-23. doi:10.3233/CH-2010-1259

168. Stull DE, Vernon MK, Legg JC, Viswanathan HN, Fairclough D, Revicki DA. Use of latent growth curve models for assessing the effects of darbepoetin alfa on hemoglobin and fatigue. Contemp Clin Trials (2010) 31(2):172-9. doi:10.1016/j.cct.2009.12.006

169. Tjulandin SA, Bias P, Elsässer R, Gertz B, Kohler E, Buchner A. Epoetin theta in anaemic cancer patients receiving platinum-based chemotherapy: a randomised controlled trial. Arch Drug Inf (2010) 3(3):45-53. doi:10.1111/j.17535174.2010.00030.x

170. Hoskin PJ, Robinson M, Slevin N, Morgan D, Harrington K, Gaffney C. Effect of epoetin alfa on survival and cancer treatment-related anemia and fatigue in patients receiving radical radiotherapy with curative intent for head and neck cancer. J Clin Oncol (2009) 27(34):5751-6. doi:10.1200/JCO.2009.22.3693

171. Vansteenkiste J, Dooms C, De Leyn P. The multidisciplinarity of stage III nonsmall cell lung cancer. Eur J Cancer (2009) 45(Suppl 1):92-105. doi:10.1016/ S0959-8049(09)70021-8

172. Grobmyer SR, Hemming AW, Harris N, Behrns K, Logan H, Kim RD, et al. A pilot prospective randomized trial of postoperative epoetin alfa in patients undergoing major operation for upper gastrointestinal malignancy. Am J Clin Oncol (2009) 32(6):570-3. doi:10.1097/COC.0b013e31819790a8

173. Hernandez E, Ganly P, Charu V, Dibenedetto J, Tomita D, Lillie T, et al. Randomized, double-blind, placebo-controlled trial of every-3-week darbepoetin alfa 300 micrograms for treatment of chemotherapy-induced anemia. Curr Med Res Opin (2009) 25(9):2109-20. doi:10.1185/03007990903084164
174. Greenberg PL, Sun Z, Miller KB, Bennett JM, Tallman MS, Dewald G, et al. Treatment of myelodysplastic syndrome patients with erythropoietin with or without granulocyte colony-stimulating factor: results of a prospective randomized phase 3 trial by the Eastern Cooperative Oncology Group (E1996). Blood (2009) 114(12):2393-400. doi:10.1182/blood-2009-03-211797

175. Repetto L, CIPOMO Investigators. Incidence and clinical impact of chemotherapy induced myelotoxicity in cancer patients: an observational retrospective survey. Crit Rev Oncol Hematol (2009) 72(2):170-9. doi:10.1016/j.critrevonc. 2009.03.004

176. Tzekova V, Mihaylov G, Elezovic I, Koytchev R, Epoetin Zeta Oncology Study Group. Therapeutic effects of epoetin zeta in the treatment of chemotherapyinduced anaemia. Curr Med Res Opin (2009) 25(7):1689-97. doi:10.1185/ 03007990903050876

177. Welsch T, Zschäbitz S, Becker V, Giese T, Bergmann F, Hinz U, et al. Prognostic significance of erythropoietin in pancreatic adenocarcinoma. PLoS One (2011) 6(8):e23151. doi:10.1371/journal.pone.0023151

178. Seibold ND, Schild SE, Gebhard MP, Noack F, Schröder U, Rades D. Prognosis of patients with locally advanced squamous cell carcinoma of the head and neck. Impact of tumor cell expression of EPO and EPO-R. Strahlenther Onkol (2013) 189(7):559-65. doi:10.1007/s00066-013-0320-7

179. Rades D, Setter C, Dahl O, Schild SE, Noack F. Prognostic impact of erythropoietin expression and erythropoietin receptor expression on locoregional control and survival of patients irradiated for stage II/III non-small-cell lung cancer. Int J Radiat Oncol Biol Phys (2011) 80(2):499-505. doi:10.1016/j.ijrobp.2010. 02.003

180. Lin YT, Chuang HC, Chen CH, Armas GL, Chen HK, Fang FM, et al. Clinical significance of erythropoietin receptor expression in oral squamous cell carcinoma. BMC Cancer (2012) 12:194. doi:10.1186/1471-2407-12-194

181. Volgger B, Kurz K, Zöschg K, Theurl I, Ciresa-König A, Marth C, et al. Importance of erythropoetin receptor expression in tumour tissue for the clinical course of breast cancer. Anticancer Res (2010) 30(9):3721-6.

182. Giatromanolaki A, Fiska A, Pitsiava D, Kartalis G, Koukourakis MI, Sivridis E. Erythropoietin receptors in endometrial carcinoma as related to HIF1\{alpha\} and VEGF expression. In vivo (2009) 23(5):699-703.

183. Küster O, Simon P, Mittelbronn M, Tabatabai G, Hermann C, Strik H, et al. Erythropoietin receptor is expressed in meningiomas and lower levels are associated with tumour recurrence. Neuropathol Applied Neurobiol (2009) 35(6):555-65. doi:10.1111/j.1365-2990.2009.01021.x

184. Gombos Z, Danihel L, Repiska V, Acs G, Furth E. Expression of erythropoietin and its receptor increases in colonic neoplastic progression: the role of hypoxia in tumorigenesis. Indian J Pathol Microbiol (2011) 54(2):273-8. doi:10.4103/0377-4929.81591

185. Beschorner R, Psaras T, Meyermann R, Bremer J, Schmidt T, Mittelbronn M, et al. Erythropoietin receptor expression in normal and neoplastic choroid plexus. Clin Neuropathol (2011) 30(1):33-40. doi:10.5414/NPP30033

186. Xu C, Zhou T, He M, Sun Y. Differential up-regulation of erythropoietin and its receptor in benign and malignant prostatic tissue. Urol Oncol (2010) 28(3):314-9. doi:10.1016/j.urolonc.2008.09.023

187. Mirmohammadsadegh A, Marini A, Gustrau A, Delia D, Nambiar S, Hassan $\mathrm{M}$, et al. Role of erythropoietin receptor expression in malignant melanoma. $J$ Invest Dermatol (2010) 130(1):201-10. doi:10.1038/jid.2009.162

Conflict of Interest Statement: The authors declare that the research was conducted in the absence of any commercial or financial relationships that could be construed as a potential conflict of interest.

Received: 31 July 2014; accepted: 22 October 2014; published online: 11 November 2014.

Citation: Debeljak N, Solár P and Sytkowski AJ (2014) Erythropoietin and cancer: the unintended consequences of anemia correction. Front. Immunol. 5:563. doi: 10.3389/fimmu. 2014.00563

This article was submitted to Inflammation, a section of the journal Frontiers in Immunology.

Copyright () 2014 Debeljak, Solár and Sytkowski. This is an open-access article distributed under the terms of the Creative Commons Attribution License (CC BY). The use, distribution or reproduction in other forums is permitted, provided the original author(s) or licensor are credited and that the original publication in this journal is cited, in accordance with accepted academic practice. No use, distribution or reproduction is permitted which does not comply with these terms. 